\title{
Thresholds for post-rebound SHIV control after CCR5 gene-edited autologous hematopoietic cell transplantation
}

\section{E Fabian Cardozo-Ojeda1*, Elizabeth R Duke ${ }^{1,2}$, Christopher W Peterson ${ }^{2,3,4}$, Daniel B Reeves' ${ }^{1}$, Bryan T Mayer ${ }^{1}$, Hans-Peter Kiem ${ }^{2,3,4,5}$, Joshua T Schiffer ${ }^{1,2,3 *}$}

${ }^{1}$ Vaccine and Infectious Disease Division, University of Washington, Seattle, United States; ${ }^{2}$ Department of Medicine, University of Washington, Seattle, United States; ${ }^{3}$ Clinical Research Division, Fred Hutchinson Cancer Research Center, Seattle, United States; ${ }^{4}$ Stem Cell and Gene Therapy Program, Fred Hutchinson Cancer Research Center, Seattle, United States; ${ }^{5}$ Department of Pathology, University of Washington, Seattle, United States

Abstract Autologous, CCR5 gene-edited hematopoietic stem and progenitor cell (HSPC) transplantation is a promising strategy for achieving HIV remission. However, only a fraction of HSPCs can be edited ex vivo to provide protection against infection. To project the thresholds of CCR5-edition necessary for HIV remission, we developed a mathematical model that recapitulates blood T cell reconstitution and plasma simian-HIV (SHIV) dynamics from SHIV-1157ipd3N4-infected pig-tailed macaques that underwent autologous transplantation with CCR5 gene editing. The model predicts that viral control can be obtained following analytical treatment interruption (ATI) when: (1) transplanted HSPCs are at least fivefold higher than residual endogenous HSPCs after total body irradiation and (2) the fraction of protected HSPCs in the transplant achieves a threshold (76-94\%) sufficient to overcome transplantation-dependent loss of SHIV immunity. Under these conditions, if ATI is withheld until transplanted gene-modified cells engraft and reconstitute to a steady state, spontaneous viral control is projected to occur.

\section{Introduction}

The major obstacle to HIV-1 eradication is a latent reservoir of long-lived, infected cells (Chun et al., 1997; Chun et al., 1995; Finzi et al., 1997). Cure strategies aim to eliminate all infected cells or permanently prevent viral reactivation from latency. The only two known cases of HIV cure, the 'Berlin Patient' and 'London Patient', resulted from allogeneic hematopoietic stem cell (HSC) transplant with homozygous CCR5 32 donor cells (Allers et al., 2011; Hütter et al., 2009; Gupta et al., 2019; Gupta et al., 2020), a mutation that makes cells resistant to CCR5-tropic HIV-1. The Berlin Patient was diagnosed with HIV in 1995 and received total body irradiation and allo-HSC transplantation for the treatment of his acute myeloid leukemia in 2007 and 2008. On the day of his first transplantation, antiretroviral therapy (ART) was interrupted, and HIV viremia never returned (Allers et al., 2011; Hütter et al., 2009; Peterson and Kiem, 2019). In 2019, an HIV-1 remission for more than 18 months was reported in the London Patient as part of the IciSTEM cohort (Gupta et al., 2019). The London Patient underwent one allo-HSC transplantation for treatment of Hodgkin Lymphoma in 2016, but with a less aggressive conditioning compared to the Berlin patient without irradiation (Gupta et al., 2019). This individual stopped ART 17 months after transplantation and as of March, 2020 his viremia remains suppressed, representing a possible case of HIV-1 cure (Gupta et al., 2020). The success of the allo-HSC transplantation is likely multifactorial-in part attributable to HIV resistance of the transplanted cells, the conditioning regimen that facilitates engraftment and 


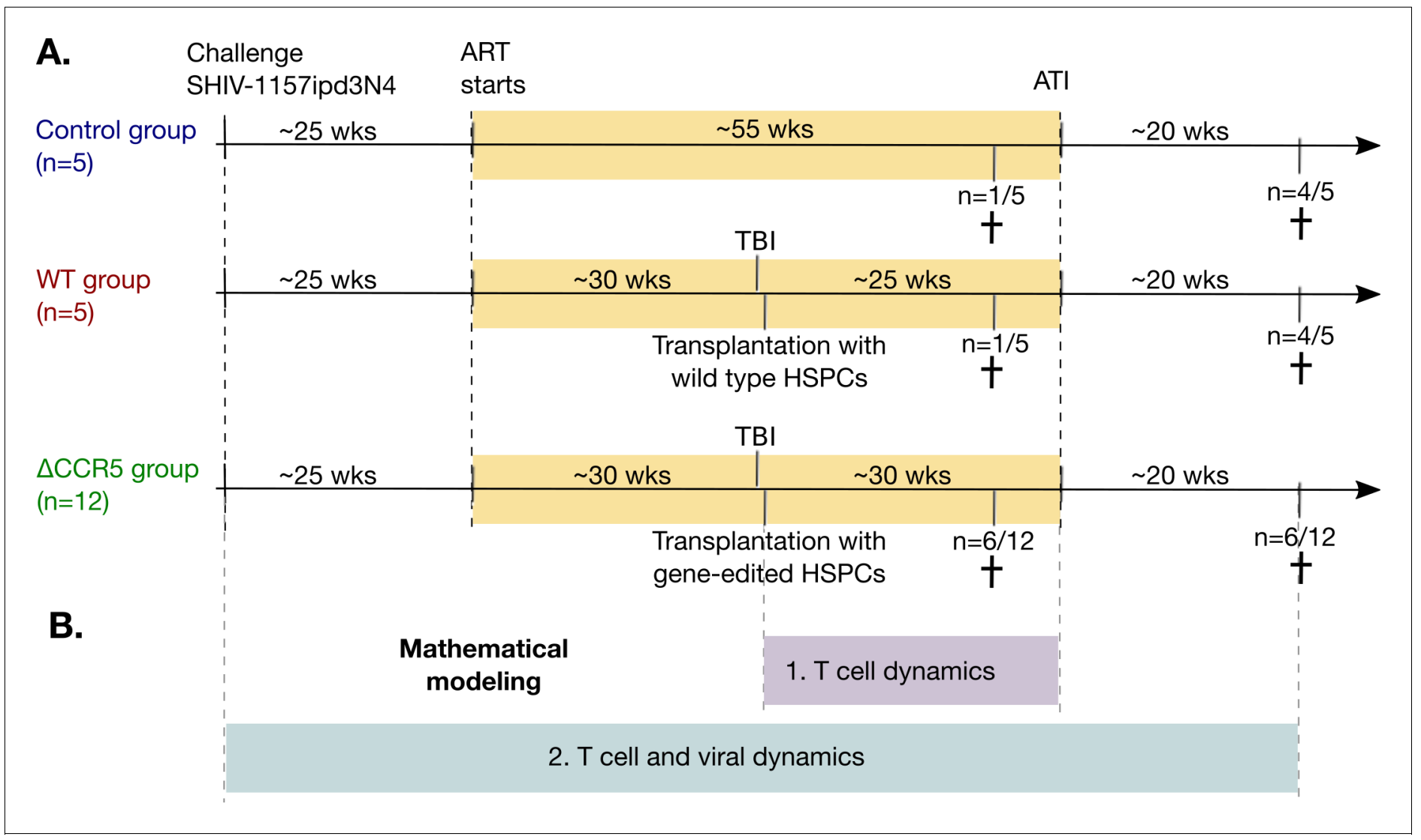

Figure 1. Study design and mathematical modeling. (A) Twenty-two pig-tailed macaques were infected with SHIV and suppressed with ART. Next, 17/ 22 underwent hematopoietic stem and progenitor cell (HSPC) transplantation following myeloablative conditioning (TBI), including 12 animals that received CCR5-edited products and five that received non-edited products ( $\triangle$ CCR5 and WT groups, respectively). A control group ( $n=5)$ did not receive TBI or HSPC transplantation. Fourteen animals underwent ATI approximately 1 year after ART initiation, while the remaining eight animals were necropsied prior to ATI (see Materials and methods for details). (B) We first developed mathematical models for T cell dynamics and reconstitution following transplant and before ATI (purple), assuming that low viral loads on ART do not affect cell dynamics. After validation of that model, we introduced viral dynamics and fit those to the T cell, primary infection, and viral rebound dynamics from the animals pre- and post-ATI (blue).

eliminates infected cells, graft-versus-host effect against residual infected cells, and immunosuppressive therapies for graft-versus-host disease (Henrich et al., 2016; Henrich et al., 2014; Henrich et al., 2013; Salgado et al., 2018).

We are interested in recapitulating this method of cure but with reduced toxicity. Specifically, we are investigating the use of autologous transplantation following ex vivo inactivation of the CCR5 gene with gene-editing (Tebas, 2014; Peterson et al., 2016). This procedure is safe and feasible in pigtail macaques infected with simian-HIV (SHIV) (Peterson et alı, 2016; Peterson et al., 2017; Peterson et al., 2018) and is currently being investigated in a Phase I clinical trial in suppressed, HIV-1-infected humans (NCT02500849). Also, this approach is more broadly applicable because an allogeneic CCR5-negative donor is not needed. However, current data suggests that protocols do not achieve sufficient fractions of genetically modified HIV-resistant hematopoietic stem and progenitor cells (HSPCs). In contrast, in allogeneic transplant, nearly $100 \%$ of circulating immune cells after engraftment consist of donor-derived CCR $5 \Delta 32$ cells. This leads to a key question: what threshold percentage of CCR5-edited, autologous HSPCs is necessary for the cure/long-term remission observed in the Berlin and London patients?

To answer this question, we developed a mathematical model that predicts the minimum threshold of gene-modified cells necessary for functional cure. First, we modeled the kinetics of CD4 ${ }^{+}$ $\mathrm{CCR}^{+}, \mathrm{CD}^{+} \mathrm{CCR5}^{-}$, and $\mathrm{CD}^{+}{ }^{+} \mathrm{T}$ cell reconstitution after autologous transplantation. Then, we modeled SHIV kinetics during acute infection and rebound following ATI to identify the degree of loss of anti-HIV cytolytic immunity following transplantation as presented before but including some 


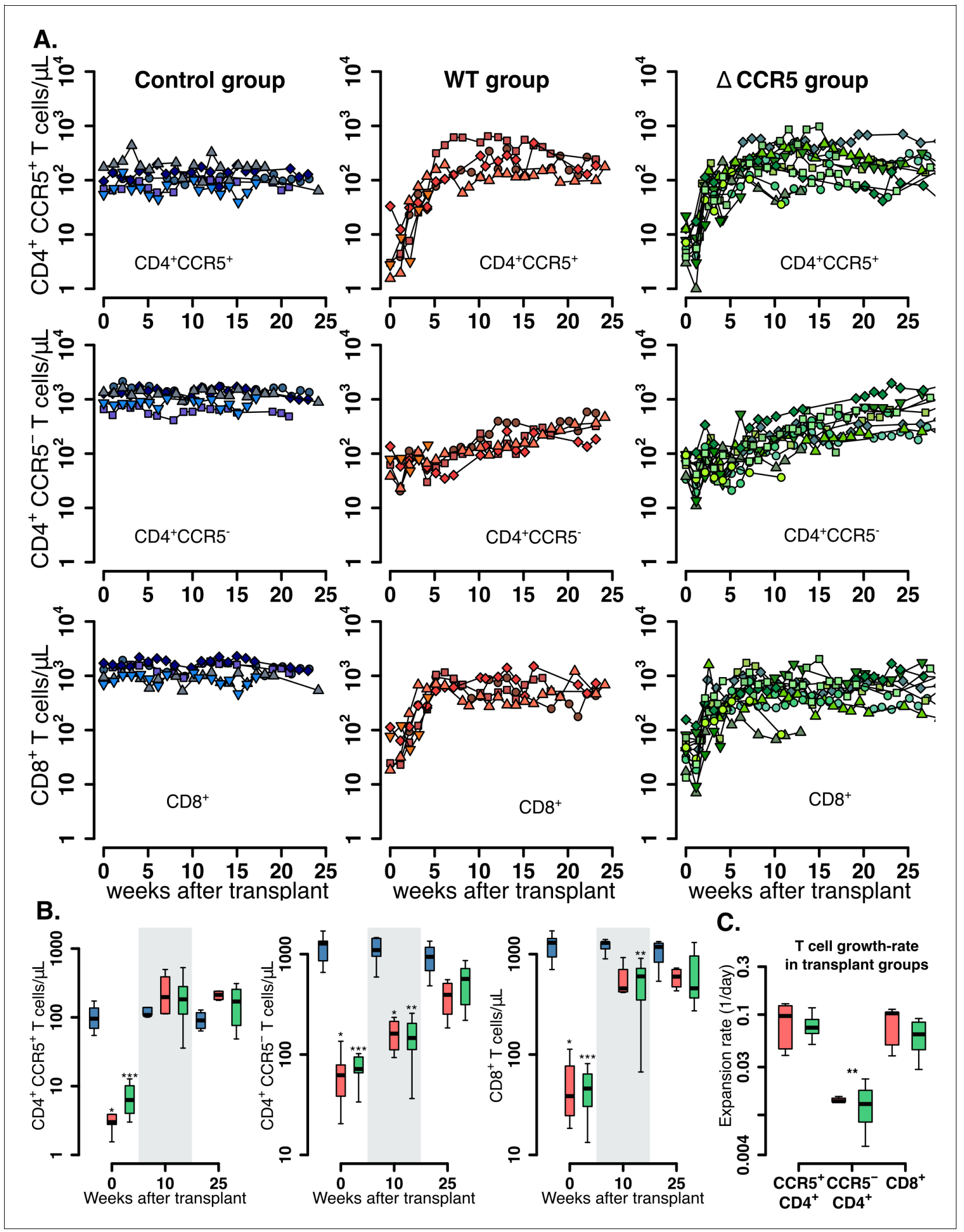

Figure 2. Post-transplantation, pre-ATI CD4 ${ }^{+}$and $\mathrm{CD} 8^{+} \mathrm{T}$ cell dynamics. (A) Empirical data for peripheral $\mathrm{CD} 4^{+} \mathrm{CCR} 5^{+}$(top row), $\mathrm{CD} 4^{+} \mathrm{CCR} 5^{-}$(middle row), and CD8 ${ }^{+} \mathrm{T}$ cell counts (bottom row) for control (blue), wild-type (red), and $\triangle \mathrm{CCR} 5$ (green) transplantation groups. Each data point shape and color is a different animal sampled over time. (B) Distributions of blood CD4 ${ }^{+}$and $C D 8^{+} \mathrm{T}$ cell counts for weeks 0,10 , and 25 after transplantation ( $\mathrm{p}-$ values calculated with pairwise Mann-Whitney test with Bonferroni correction comparing control group with transplant groups. ${ }^{*} p<0.05,{ }^{\star *} p<0.01$ and Figure 2 continued on next page 
Figure 2 continued

${ }^{* * *} \mathrm{p}<0.001$ ). (C) Expansion-rate estimates of $\mathrm{CD} 4^{+} \mathrm{CCR} 5^{+}, \mathrm{CD} 4^{+} \mathrm{CCR} 5^{-}$, and $\mathrm{CD} 8^{+} \mathrm{T}$ cells ( $\mathrm{p}$-values calculated with paired Mann-Whitney test with Bonferroni correction comparing expansion rates of $\mathrm{CD} 4^{+} \mathrm{CCR} 5{ }^{-}$with $\mathrm{CD} 4^{+} \mathrm{CCR} 5^{+}$and $\mathrm{CD} 8^{+}$in transplant groups. ${ }^{* *} \mathrm{p}<0.01$ for both). Colors for boxplots in $\mathrm{B}$ and $\mathrm{C}$ are matched to $\mathrm{A}$ (blue: control, red: wild-type-transplantation, and green: $\triangle$ CCR5-transplantation groups).

The online version of this article includes the following source data, source code and figure supplement(s) for figure 2 :

Source code 1. R code for plots and tests in Figure 2.

Source data 1. Complete data set of blood T cell counts for Figures 2 and 3.

Figure supplement 1. $\mathrm{CD}^{+}$and $C D 8^{+} \mathrm{T}$ cell levels pre-ATI in control group $(n=5)$ at times relative to post-transplantation in WT and $\Delta C C R 5$

transplant groups.

additional data (Peterson et alı, 2017; Reeves et alı, 2017). Finally, we applied our models to predict the proportion of gene-modified cells, the dose of these cells relative to the intensity of the preparative conditioning regimen (total body irradiation, TBI), and the levels of SHIV-specific immunity required to maintain virus remission following ATI. Results from this three-part modeling approach support strategies that (1) increase stem cell dose, (2) enhance potency of conditioning regimen to reduce the number of endogenous HSPCs that compete with transplanted CCR5-edited HSPCs, (3) increase the fraction of gene-modified SHIV-resistant cells, (4) extend periods between HSPC transplantation and ATI with tracking of CCR5- cell recovery and/or (5) augment anti-HIV immunity to achieve sustained HIV remission.

\section{Results}

\section{Study design and mathematical modeling}

We analyzed data from 22 juvenile pig-tailed macaques that were intravenously challenged with 9500 TCID50 SHIV1157ipd3N4 (SHIV-C) (Figure 1A). After 6 months of infection, the macaques received combination ART that included tenofovir (PMPA), emtricitabine (FTC), and raltegravir (RAL). When on ART, 17/22 received total body irradiation (TBI) followed by the transplantation of autologous HSPCs with $(n=12)$ or without $(n=5)$ CCR5 gene editing ( $\triangle$ CCR5 and WT groups, respectively). A control group $(n=5)$ did not receive TBI or HSPC transplantation. 14 of the animals underwent ATI approximately 1 year after ART initiation. The remaining eight animals were necropsied at an earlier time relative to the other animals' ATI (see Materials and methods for details).

To analyze the data and estimate thresholds for viral control under this approach, we used ordinary differential equation models. We performed multi-stage modeling (Figure 1B). First, we modeled the kinetics of $\mathrm{CD}^{+}$and $\mathrm{CD}^{+} \mathrm{T}$ cell subsets after autologous HSPC infusion following transplant and before ATI, assuming that ART suppression decouples SHIV-dynamics from cellular dynamics. After validation of the first-stage model, we introduced a second-stage of modeling to (1) explain virus and T cell kinetics during primary infection and ATI and to (2) identify the degree of loss of anti-HIV cytolytic immunity due to the preparative conditioning. Then, we used the final validated model to project SHIV kinetics assuming different transplantation conditions.

\section{$\mathrm{CD}^{+}{ }^{+} \mathrm{CR} 5^{+}$and $\mathrm{CD}^{+}{ }^{+}$cells recover more rapidly than $\mathrm{CD}^{+} \mathrm{CCR5}-\mathrm{T}^{-}$ cells after HSPC transplantation}

We analyzed the kinetics of peripheral blood $\mathrm{CD} 4^{+} \mathrm{CCR} 5^{+}$and $\mathrm{CD} 4^{+} \mathrm{CCR} 5^{-} \mathrm{T}$ cells, and total, $\mathrm{T}_{\text {naive, }}$ $\mathrm{T}_{\mathrm{CM}}$, and $\mathrm{T}_{\mathrm{EM}} \mathrm{CD}^{+} \mathrm{T}$ cells in macaques after HSPC transplantation.

In untransplanted controls, levels of $\mathrm{CD}^{+}$and $\mathrm{CD}^{+} \mathrm{T}$ cells oscillated around a persistent set point (blue data-points in Figure 2A). Also, $\mathrm{CD} 4^{+} \mathrm{CCR} 5^{+} \mathrm{T}$ cell levels were $\sim 100 \mathrm{cells} / \mu \mathrm{L}$ and were uniformly lower than the $\mathrm{CD}^{+}{ }^{+} \mathrm{CCR} 5^{-} \mathrm{T}$ counts (each $\sim 1000$ cells/ $\mu \mathrm{L}$ ) (Figure 2 -figure supplement 1A). Finally, total $C D 8^{+} \mathrm{T}$ cell levels in the control group were $\sim 1400$ cells/ $\mu \mathrm{L}$ with a greater contribution from $\mathrm{T}_{\mathrm{EM}}$ (73\%) than $\mathrm{T}_{\mathrm{N}}+\mathrm{T}_{\mathrm{CM}}$ (27\%) (based on median values, Figure 2-figure supplement 1).

In the transplant groups, post-TBI levels of $\mathrm{CD}^{+}{ }^{+} \mathrm{CCR} 5^{+}, \mathrm{CD}^{+}{ }^{+} \mathrm{CCR} 5$, and $\mathrm{CD}^{+}{ }^{-} \mathrm{T}$ cells were significantly lower than in the control group but expanded at different rates during the following weeks (Figure $2 \mathrm{~A}-\mathrm{C}$ ). The levels of $\mathrm{CD} 4^{+} \mathrm{CCR} 5^{+} \mathrm{T}$ cells started at $1-10 \mathrm{cells} / \mu \mathrm{L}$ and reconstituted to levels similar to the control group over 5-10 weeks (Figure $2 A-B$ ). CD4 ${ }^{+}$CCR5 ${ }^{-} \mathrm{T}$ cells remained at higher levels $(\sim 100$ cells $/ \mu \mathrm{L})$ than $\mathrm{CD} 4^{+} \mathrm{CCR} 5^{+} \mathrm{T}$ cells after TBI but expanded more slowly and did not reach 
A.

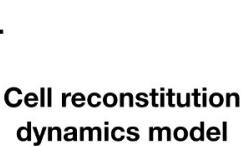
dynamics model

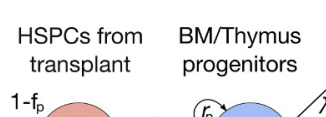

$1-\mathrm{f}_{\mathrm{p}}$

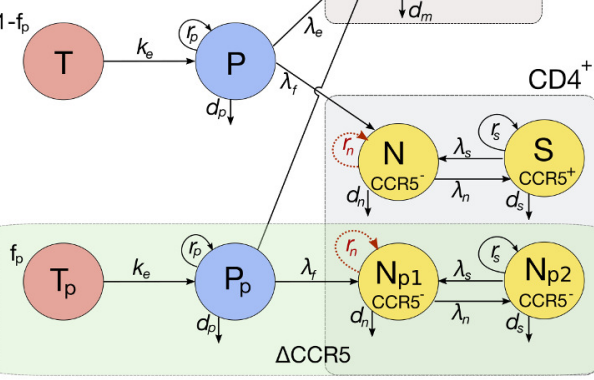

C.

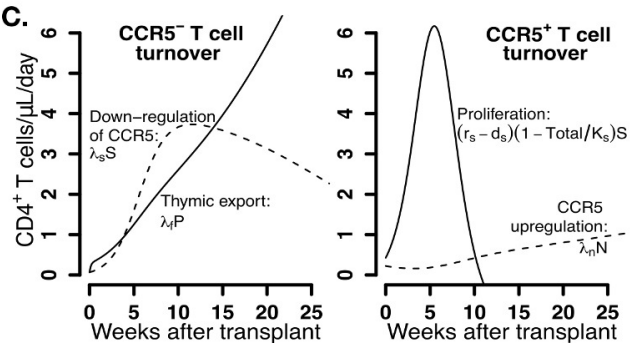

B.
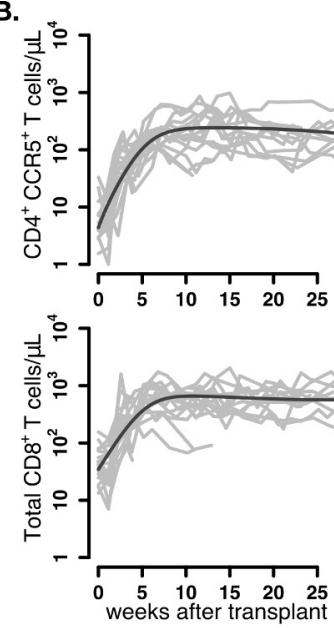
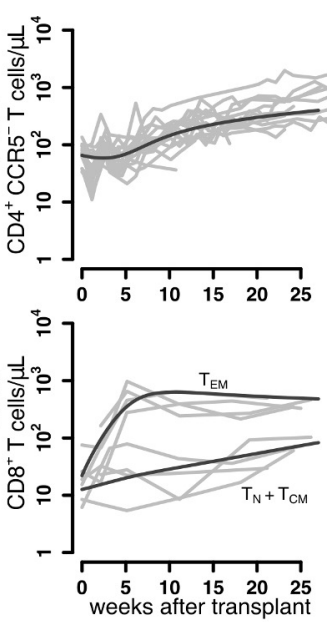

Figure 3. Mathematical model of $T$ cell reconstitution after hematopoietic stem and progenitor cell (HSPC) transplantation. (A) Schematics of the model. Each circle represents a cell compartment: T represents the HSPCs from the transplant; $P$, the progenitor cells in bone marrow $(B M)$ and thymus; $\mathrm{S}$ and $\mathrm{N}, \mathrm{CD} 4^{+} \mathrm{CCR} 5^{+}$and $\mathrm{CD4}^{+} \mathrm{CCR} 5^{-} \mathrm{T}$ cells, respectively; $\mathrm{T}_{\mathrm{p}}$, the protected ( $\left.\triangle \mathrm{CCR} 5\right)$, gene-modified cells from transplant; $\mathrm{P}_{\mathrm{p}}$, protected $(\Delta C C R 5)$ progenitor cells in BM/thymus; $N_{p 1}$ and $N_{p 2}$ the protected ( $\triangle$ CCR5) CD4 ${ }^{+} T$ cells; $M$ the $C D 8^{+} T$ cells with naive and central memory phenotype and $\mathrm{E} \mathrm{CD} 8^{+} \mathrm{T}$ cells with effector memory phenotype. The initial fraction of protected cells in the product is represented by the parameter $\mathrm{f}_{\mathrm{p}}$. Gray panels represent mature blood $\mathrm{CD} 4^{+}$and $\mathrm{CD}^{+} \mathrm{T}$ cells, and the green panel all $\triangle \mathrm{CCR} 5$ cells in the model. Red, dashed arrows represent discarded terms after model selection and validation (see text for details). (B) Model predictions using the maximum likelihood estimation of the population parameters (solid black lines) for all blood T cell subsets before ATI for all animals in the transplant groups using model with $\triangle \mathrm{AIC}=0$ (Figure 3-source datas 2-3). Each gray line is one animal. (C) Model predictions of the total concentration of $\mathrm{CD}^{+}{ }^{+} \mathrm{CCR} 5-\mathrm{T}$ cells generated by $\mathrm{CCR} 5$ downregulation (dashed line) or thymic export (solid line), and of the total concentration of $\mathrm{CD} 4^{+} \mathrm{CCR} 5^{+} \mathrm{T}$ cells generated by proliferation (solid line) or by upregulation of CCR5 (dashed line) over time using the maximum likelihood estimation of the population parameters.

The online version of this article includes the following source data, source code and figure supplement(s) for figure 3:

Source code 1. Best model file for T cell reconstitution in Monolix format.

Source code 2. $R$ code for plots in Figure 3.

Source data 1. Values of the fraction of protected cells in transplant product $f_{p}$, dose or number of hematopoietic stem and progenitor cell (HSPCs) in transplant product $D$ and time of transplantation $t_{x}$ of each animal for model fitting and projections.

Source data 2. Competing models for fitting $T$ cell reconstitution with respective AIC values.

Source data 3. Population parameter estimates for the best fits of the model in Equation 2 in the main text (lowest AIC in Figure 3-source data 2) to the T cell reconstitution dynamics.

Source data 4. Individual parameter estimates for the best fits of the model in Equation 2 in the main text (lowest AIC in Figure 3-source data 2) to the T cell reconstitution dynamics.

Source data 5. Population parameter estimates for the best fits used in the R code for Figure 3.

Figure supplement 1. Individual fits of the best model to the blood T cell observations pre-ATI in control group from a time relative to post-transplantation in transplant groups.

Figure 3 continued on next page 
Figure 3 continued

Figure supplement 2. Individual fits of the best model to the blood T cell observations post-transplantation, preATI for the wild-type-transplant group.

Figure supplement 3. Individual fits of the best model to the blood T cell observations post-transplantation, preATI for the $\triangle$ CCR5-transplant group.

Figure supplement 4. Predictions of the best model for the contributors to cell expansion in CD8+ TEM cells in animals from the transplant groups.

the values of the control group after 25 weeks (Figure $2 \mathrm{~A}-\mathrm{B}$ ). The $\mathrm{CD} 4^{+} \mathrm{CCR} 5^{+} \mathrm{T}$ cell compartment expanded eightfold more rapidly than the $C D 4^{+} C C R 5^{-}$compartment $(p=0.008$, paired Mann-Whitney test, Figure $2 \mathrm{C}$ ). $\mathrm{CD}^{+} \mathrm{T}$ cells decreased to levels between 10 and $100 \mathrm{cells} / \mu \mathrm{L}$ after TBI but recovered to levels just below the control group in 5 weeks (Figure $2 \mathrm{~A}-\mathrm{B}$ ); $\mathrm{CD} 8^{+} \mathrm{T}$ cells recovered as rapidly as the $\mathrm{CD} 4^{+} \mathrm{CCR} 5^{+}$population (Figure $2 \mathrm{C}$ ).

Overall, these results show that after transplantation $\mathrm{CD} 4{ }^{+} \mathrm{CCR} 5^{+}$and $\mathrm{CD} 8^{+} \mathrm{T}$ cells recover faster than $\mathrm{CD}^{+}{ }^{+} \mathrm{CCR} 5^{-}$cells. This suggests that each cell subset may have different and/or complementary mechanisms that drive their expansion. To explore these mechanisms, we analyzed the data with a mechanistic mathematical model of cellular dynamics.

\section{Lymphopenia-induced proliferation drives early $\mathrm{CD}^{+}{ }^{+} \mathrm{CR} 5^{+}$and $\mathrm{CD} 8^{+}$ T cell reconstitution after HSPC transplantation}

To identify the main drivers of $T$ cell reconstitution after transplant, we developed a mathematical model that considered plausible mechanisms underlying reconstitution of distinct $T$ cell subsets following autologous transplantation (Figure 3A). We assumed that $\mathrm{T}$ cell reconstitution may have two main drivers: (1) lymphopenia-induced proliferation of mature cells that persist through myeloablative TBI (Jameson, 2002; Schluns et al., 2002; Schluns et alı, 2000; Goldrath et al., 2004; Voehringer et alo, 2008) and (2) differentiation from naive cells from progenitors in the thymus (from transplanted CD34+ HSPCs (Douek et al., 2000; Douek et al., 1998) or residual endogenous $\mathrm{CD} 4^{+}$HSPCs that persist following TBI) and further differentiation to an activated effector state (Voehringer et al., 2008; Bender et al., 1999; Kieper and Jameson, 1999; Sallusto et al., 2004; Le Saout et al., 2008; Sprent and Surh, 2011). We also assumed the infused product dose $D$ contains a fraction $f_{p}$ of transplanted, gene-edited HSPCs that do not express CCR5 (see Figure 3source data 1 for individual values of $D$ and $f_{p}$ ). Thus, in our model, $\Delta$ CCR5-gene-modified CD4 ${ }^{+} \mathrm{T}$ cells differentiating from these modified HSPCs are a subset of the total CD4 ${ }^{+} \mathrm{CCR} 5^{-}$cell compartment (Figure 3A).

We built 24 versions of the model by assuming that one or multiple mechanisms are absent, or by assuming certain mechanisms have equivalent or differing kinetics (Figure 3-source data 2). Using model selection theory, we identified the most parsimonious model that reproduced the data (schematic in Figure 3A without red-dashed lines). The best model predictions for each cell subset using maximum likelihood estimates of the population parameters (Figure 3-source data 3) are presented in Figure 3B. Individual fits are visualized in Figure 3-figure supplement 13 and parameter estimates are collected in Figure 3-source data 4.

Model selection illuminated several likely biological phenomena: (1) $\mathrm{CD} 4^{+} \mathrm{CCR} 5^{+} \mathrm{T}$ cell reconstitution after transplant is determined by cell proliferation and to a minor degree by upregulation of CCR5 (Figure 3C); (2) CD4 ${ }^{+}$CCR5 ${ }^{-} \mathrm{T}$ cell expansion is driven primarily by new naive cells from the thymus and to a lesser extent by CCR5 downregulation (Figure 3C); and (3) thymic export is not significantly different for $\mathrm{CD}^{+}$or $\mathrm{CD}^{+} \mathrm{T}$ cells (Figure 3-source data 2). However, model selection could not distinguish between the two models where $\triangle$ CCR5-gene-modified $\mathrm{CD} 4^{+} \mathrm{T}$ cells have the kinetics of both non-modified $\mathrm{CD} 4{ }^{+} \mathrm{CCR} 5^{+}$and $\mathrm{CD} 4^{+} \mathrm{CCR} 5^{-}$versus only the kinetics of non-modified $\mathrm{CD}^{+} \mathrm{CCR}^{-}$(i.e. having compartment $\mathrm{N}_{p 2}$ or not in Figure $3 \mathrm{~A}$ ). Regardless, these two best models were identical in all other respects (Figure 3-source datas 2 and 3).

This first-stage modeling suggested additional testable biological predictions. First, the estimated $\mathrm{CD}^{+}{ }^{+} \mathrm{CCR}^{+} \mathrm{T}$ cell proliferation rate $(-0.1 /$ day) far exceeds the estimated CCR5 upregulation $(\sim 0.004 /$ day $)$ and thymic export rates ( 0.002/day). Therefore, 1 month after transplantation, the total concentration of $\mathrm{CD}^{+}{ }^{+} \mathrm{CCR}^{+}{ }^{+} \mathrm{T}$ cells generated by proliferation is predicted to be 40 -fold higher than the concentration generated by upregulation of CCR5 (Figure 3C). Second, the CD8 ${ }^{+}$ 


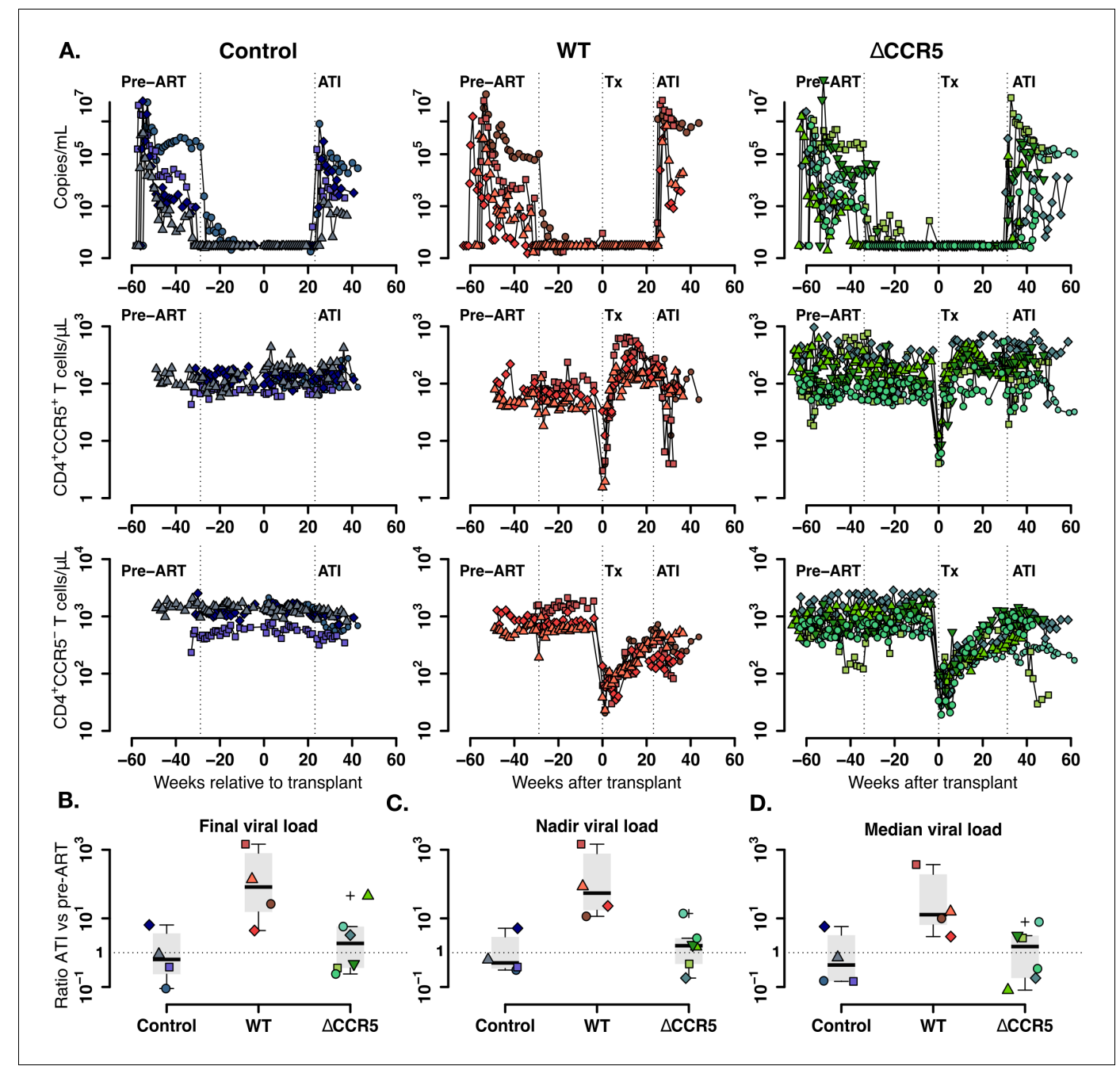

Figure 4. Plasma viral load and $C D 4^{+} T$ cell kinetics after ATI. (A) Empirical data for viral load (top row) and peripheral T cell counts (middle and bottom rows) for control (blue), wild-type (red) and $\triangle$ CCR5 (green) transplantation groups. Each data point shape and color represent a different animal sampled over time. (B) Distributions of the ratio at ATI vs pre-ART of final, nadir, and median viral load. Dotted horizontal lines represent a ratio equal to one (or no difference between ATI vs nadir).

The online version of this article includes the following source data, source code and figure supplement(s) for figure 4:

Source code 1. R code for plots and test in Figure 4.

Source data 1. Complete data set of blood T cell counts and viral load for Figures 4 and 5.

Figure supplement 1. Blood $\mathrm{CD} 4^{+} \mathrm{CCR} 5^{+}$and $\mathrm{CD} 4^{+} \mathrm{CCR} 5-\mathrm{T}$ cell kinetics post-ATI.

$\mathrm{T}_{\mathrm{EM}}$ cells comprise the majority of the total $\mathrm{CD} 8^{+} \mathrm{T}$ cell compartment (Figure $3 \mathrm{~B}$ ) with a proliferation rate up to 10 -fold higher than the $\mathrm{CD} 8^{+} \mathrm{T}_{\mathrm{CM}}$ cell differentiation rate (Figure 3-figure supplement 4). In this way, $\mathrm{CD} 8^{+} \mathrm{T}$ cells follow a similar pattern to $\mathrm{CD} 4^{+} \mathrm{CCR} 5^{+} \mathrm{T}$ cells (Figure $3 \mathrm{~B}$ ).

In summary, following autologous HSPC transplant: (1) thymic export and downregulation of CCR5 drive a modest expansion of $\mathrm{CD}^{+}{ }^{+} \mathrm{CCR} 5^{-} \mathrm{T}$ cells, whereas (2) rapid lymphopenia-induced proliferation after $\mathrm{TBI}$ is the main driver for $\mathrm{CD}_{4}{ }^{+} \mathrm{CCR}^{+}$and $\mathrm{CD}^{+} \mathrm{T}$ cell expansion, which are derived from both the transplanted HSPC product and residual endogenous cells that persisted through the myeloablative conditioning regimen. 


\section{Plasma virus and blood CD4 ${ }^{+} \mathrm{CCR}^{+}$dynamics are heterogenous among transplanted, SHIV-infected animals}

To build a mathematical model for the virus and T cell dynamics, we analyzed plasma viral load kinetics and $\mathrm{CD}^{+}{ }^{+} \mathrm{CCR} 5^{+} / \mathrm{CCR} 5^{-} \mathrm{T}$ cell subset dynamics after ATI with respect to kinetics pre-ART (Peterson et al., 2017; Reeves et al., 2017). Figure 4A presents the plasma viral loads and the blood $\mathrm{CD}^{+} \mathrm{CCR}^{+}$and $\mathrm{CD} 4^{+} \mathrm{CCR} 5^{-} \mathrm{T}$ cell kinetics before and after transplantation in the three groups.

We calculated the ratio of the viral load at necropsy versus at initiation of ART (Figure 4B) and the ratio of the nadir and median viral load after ATI versus pre-ART (Figure 4C-D). In general, the viral burden after ATI compared to pre-ART was slightly lower for the control group. However, for transplanted animals the viral load changes were heterogeneous, having much higher ratios for the wild-type (WT) group and slightly higher for CCR5-edited ( $\triangle C C R 5$ ) group. For the three computed ratios, the viral load change after ATI was between 10- and 100-fold for the wild-type group (Figure 4B-D).

During $\mathrm{ATI}, \mathrm{CD}^{+} \mathrm{CCR}^{+} \mathrm{T}$ cells declined heterogeneously in the transplanted groups (Figure 4A), but $\mathrm{CD}^{+}{ }^{+} \mathrm{CCR} 5^{+} \mathrm{T}$ cell nadirs in the transplanted groups were consistently lower than those of control animals whose $\mathrm{CD} 4^{+} \mathrm{CCR} 5^{+} \mathrm{T}$ cell levels did not decrease (Figure 4-figure supplement 1A). On the other hand, blood $\mathrm{CD}^{+}{ }^{+} \mathrm{CCR} 5^{-} \mathrm{T}$ cell levels decreased to a similar nadir in all groups during ATI (Figure 4A and Figure 4-figure supplement 1B).

To summarize, SHIV viral load and $\mathrm{CD} 4^{+} \mathrm{CCR} 5^{+}$dynamics are heterogeneous among transplanted animals. Higher ATI versus pre-ART viral load ratios in transplanted animals suggest that transplantation affects the host response against SHIV-replication, but this damage to host response may be mitigated somewhat when transplantation includes CCR5-edition.

\section{A reduction in SHIV-specific immunity leads to higher viral rebound set points following ATI in transplanted animals}

We simultaneously analyzed the viral and T cell subset data using mechanistic mathematical models in order to recapitulate the heterogeneity of plasma viral load and $\mathrm{CD} 4^{+} \mathrm{CCR} 5^{+} \mathrm{T}$ cell kinetics and how transplantation may modify the immune response during ATI compared to the pre-ART stage. We extended our $\mathrm{T}$ cell reconstitution model to include SHIV infection of $\mathrm{CD} 4^{+} \mathrm{CCR} 5^{+} \mathrm{T}$ cells (Figure 5A and Methods) and used this second-stage model to analyze virus and $\mathrm{T}$ cell dynamics during primary SHIV-infection, ART, transplant, and ATI.

Again, following model selection theory based on AIC, we compared six mechanistic models and found a parsimonious model to explain the data (Figure 5A, Figure 5-source data 1). This model simultaneously recapitulates plasma viral load and the kinetics of $\mathrm{CD}^{+} \mathrm{CCR}^{+}$and $\mathrm{CCR} 5^{-} \mathrm{T}$ cells as shown in Figure 5B and Figure 5-figure supplements 1-3 with corresponding estimated parameters in Figure 5-source datas 2 and 3. In the best fitting model, parameters related to immune response against infection: the SHIV-specific $\mathrm{CD}^{+} \mathrm{T}$ cell proliferation $\left(\omega_{8}\right)$, saturation $\left(I_{50}\right)$, and death rates $\left(d_{h}\right)$ were different during $\mathrm{ATI}$ and the pre-ART stage (see Figure 5-source data 1; Reeves et al., 2017). SHIV-specific $\mathrm{CD}^{+}$effector cells reduce virus production rather than killing infected cells (Elemans et al., 2011; Klatt et al., 2010; Wong et al., 2010), possibly by secretion of HIV-antiviral factors (Shridhar et al., 2014; Blazek et al., 2016; Zhang et al., 2002)_not explicitly included in the model. The model also suggests that infection enhances upregulation of CD $4^{+} \mathrm{CCR} 5^{-}$ $\mathrm{T}$ cells. This upregulation transiently reduces the $\mathrm{CD} 4^{+} \mathrm{CCR} 5^{-}$compartment and replenishes $\mathrm{CD} 4^{+}-$ CCR5 $^{+}$T cells after ATI (Douek et al., 2003; Okoye et al., 2007; Okoye et al., 2012). Finally, in this model, some of the $\triangle$ CCR5-gene-modified $\mathrm{CD}^{+} \mathrm{T}$ cells also have kinetics similar to non-modified $\mathrm{CD}^{+}{ }^{+} \mathrm{CCR}^{+}$cells (i.e. it includes the compartment $N_{p 2}$ as in Figure 5A), whereas this was not able to be differentiated in the first-stage modeling.

We used our model to compute the SHIV-specific $\mathrm{CD}^{+} \mathrm{T}$ cell turnover rates after ATI and during pre-ART as measures of SHIV-specific immunity $(S I)$ for each stage, that is, $S I_{A T I}=\frac{\omega_{8}^{A T I}}{d_{h}^{A T I}}$ and $S I_{\text {preART }}=\frac{\omega_{8}^{\text {preART }}}{d_{h}^{\text {preART }}}$, respectively. We found that the SHIV immunity ATI/pre-ART ratio $\left(\frac{S I_{A T I}}{S I_{\text {preART }}}\right)$ correlated negatively with the ATI/pre-ART ratio of the observed nadir and median viral loads (Figure $5 C-D$ ). In this sense, the viral burden increase during ATI (viral burden ratio $>1$ ) in animals in the transplant groups might be due to the underlying loss of the immune response to the virus $\left(\frac{S I_{A T I}}{S I_{\text {preART }}}<1\right.$, 
A.
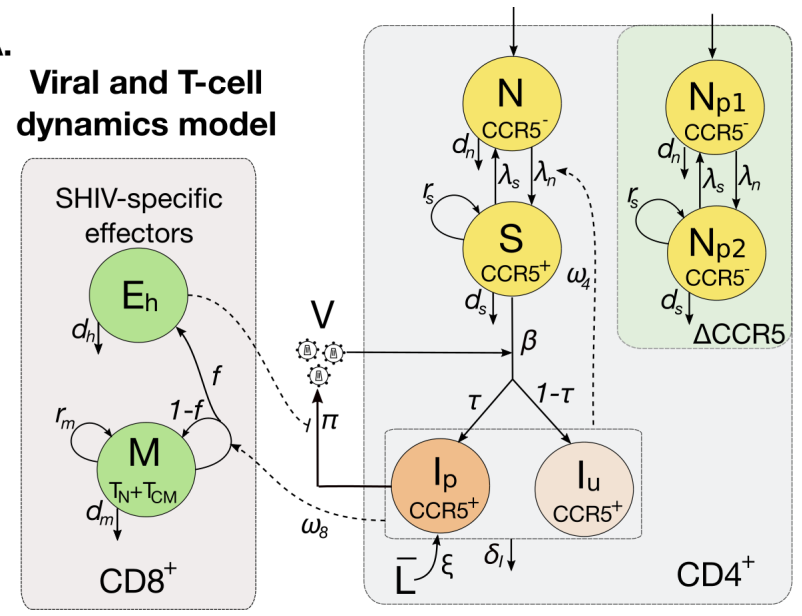

B.
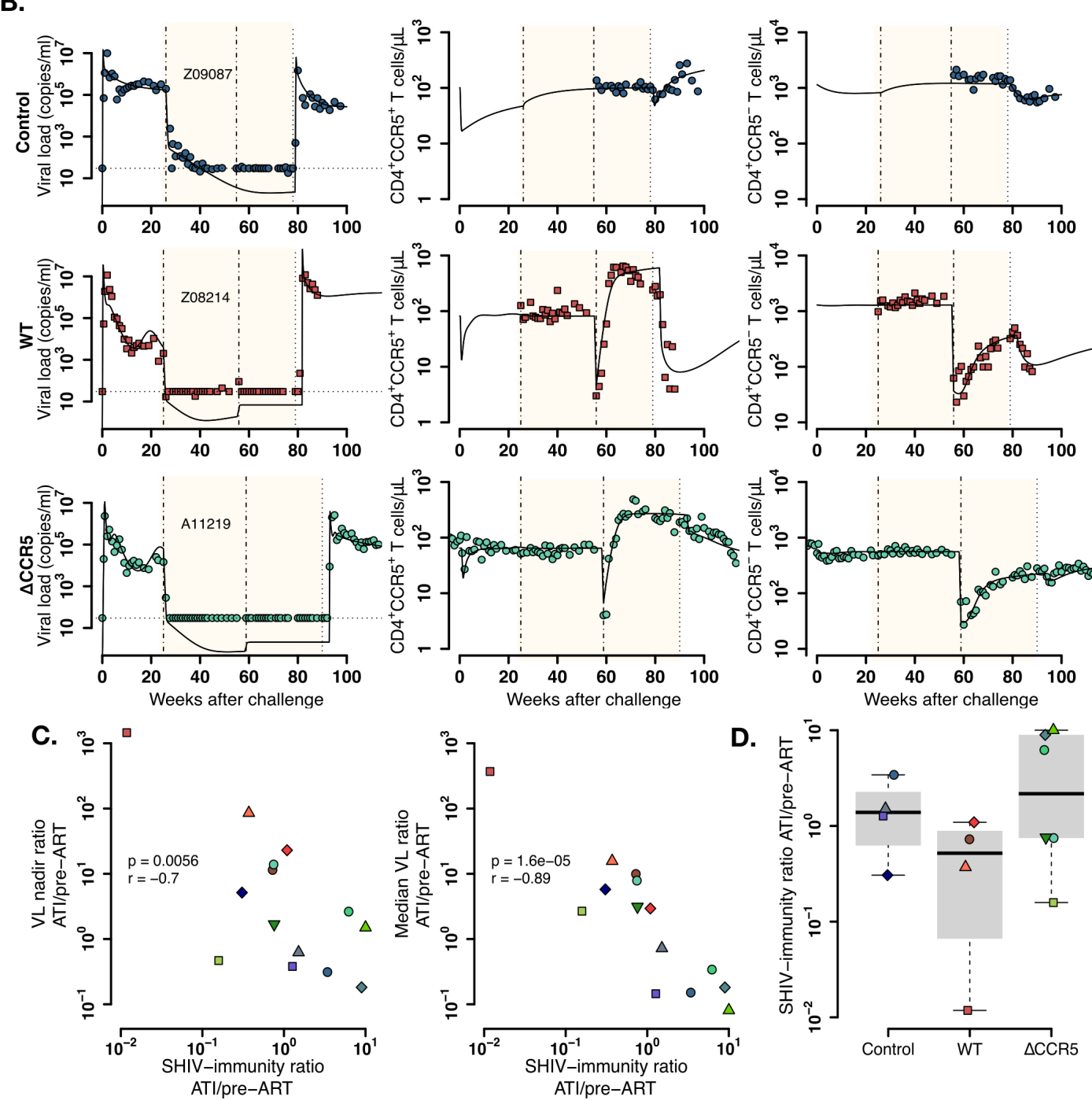

Figure 5. Mathematical model of virus and T cell dynamics following ATI. (A) Model: Susceptible cells, $S$, are infected by the virus, $V$, at rate $\beta$. I represents the fraction $\tau$ of the infected cells that produce virus, and, $I_{u}$, the other fraction that becomes unproductively infected. Total $\mathrm{CD} 4{ }^{+} \mathrm{CCR} 5^{+} \mathrm{T}$ cell count is given by the sum of $S, I_{p}$ and $I_{u}$. All infected cells die at rate $\delta_{\mid}$. Ip cells arise from activation of latently infected cells at rate $\xi \bar{L}$ and produce virus at a rate $\pi$. Virus is cleared at rate $\gamma$. CD8 ${ }^{+} \mathrm{M}$ cells proliferate in the presence of infection with rate $\omega_{8}$ from which a fraction $\mathrm{fbecome}$ SHIV-specific Figure 5 continued on next page 
Figure 5 continued

$\mathrm{CD}^{+}$effector $\mathrm{T}$ cells, $E_{h}$, that are removed at a rate $d_{h}$. These effector cells reduce virus production $(\pi)$ by $1 /\left(1+\theta E_{h}\right)$. Non-susceptible CD4 ${ }^{+} T$ cells that were not CCR5-edited upregulate CCR5 in the presence of infection and replenish the susceptible pool at rate $\omega_{4}$. Gray panels represent mature blood $\mathrm{CD}^{+}$and $\mathrm{CD}^{+} \mathrm{T}$ cells, and the green panel represents $\triangle \mathrm{CCR} 5$ cells. (B) Individual fits of the model (black lines) to SHIV RNA (left column), blood $\mathrm{CD}^{+}{ }^{+} \mathrm{CCR} 5^{+} \mathrm{T}$ cells (middle column), and $\mathrm{CD} 4^{+} \mathrm{CCR} 5^{-} \mathrm{T}$ cells (right column) for one animal in the control (top row), wild type (middle row), and $\triangle \mathrm{CCR} 5$ groups (bottom row). Shaded areas represent time during ART and dashed-point line, the time of transplantation. (C-D) Scatterplots of observed ATI/ pre-ART ratio of the $(\mathrm{C})$ nadir viral load, and the median viral load ratio versus the SHIV-specific CD8 ${ }^{+} \mathrm{T}$ immunity $\mathrm{ATI} / \mathrm{pre-ART}$ ratio: $\frac{\omega_{8}^{A T I} / d_{h}^{A T I}}{\omega_{8}^{\text {preART }} / d_{h}^{\text {PreART }}}(\mathrm{p}-\mathrm{values}$ calculated by Pearson's correlation test); a higher ratio means a better immune response post-ATI. (D) Individual estimates of the SHIV-specific CD8 ${ }^{+} \mathrm{T}$ immunity ATI/preART ratio. Blue: control, red: wild type, and green: $\triangle$ CCR5 transplant group.

The online version of this article includes the following source data, source code and figure supplement(s) for figure 5 :

Source code 1. Best model file for T cell and virus dynamics from acute infection after ATI in Monolix format.

Source code 2. $R$ code for plots in Figure 5B.

Source code 3. $R$ code for plots and tests in Figure 5C-D.

Source data 1. Competing models for fitting T cell and viral dynamics (Equations 2-3 in main text) using the best model in Figure 3-source data 2 and fixing parameter values as in Figure 3-source data 3, with AIC values.

Source data 2. Population parameter estimates for the fits of the model with lowest AIC in Figure 5-source data 1 to the T cell and virus dynamics.

Source data 3. Individual parameter estimates for the fits of the model in Equations 2-3 in main text (lowest AIC in Figure 5-source data 1) to the T cell and virus dynamics.

Source data 4. Individual parameter estimates obtained from Monolix for the best fits used in the R code for Figure 5.

Figure supplement 1. Individual fits of the best model to the blood T cell and viral load observations before/after ATI for control group.

Figure supplement 2. Individual fits of the best model to the blood T cell and viral load observations before/after ATI for the wild-type-transplant group.

Figure supplement 3. Individual fits of the best model to the blood T cell and viral load observations before/after ATI for the $\Delta$ CCR5-transplant group.

Figure 5C-D). Similarly, decrease in viral burden during ATI (viral burden ratio $<1$ ) in animals in control and $\triangle$ CCR5 groups might be due immune response memory or its recovery, respectively $\left(\frac{S I_{A T I}}{S I_{\text {preART }}}>1\right.$, Figure $\left.5 C-D\right)$.

In conclusion, we developed a second-stage model that simultaneously recapitulates viral and T cell dynamics from SHIV-infected animals receiving autologous HSPC transplantation. The model suggests that transplant may reduce host T-cell immunity resulting in higher viral loads after ATI compared to the pre-ART stage. However, SHIV immunity might be recovered if CCR5 disruption is added in the transplant resulting in lower viral loads after ATI.

\section{Post-ATI viral control requires a large HSPC dose containing a high fraction of CCR5-edited cells}

An important advantage of our model is the ability to calculate the conditions required for post-ATI viral control (viral load set point $<30$ copies/ml) after CCR5-edited autologous transplant. To this end, we used our second-stage model to approximate an effective reproductive ratio $R_{\text {eff }}$ to describe the ability of the virus to sustain infection after ATI in transplanted animals (see Materials and methods):

$$
R_{e f f}=R_{T}\left(1-\frac{f_{p} D}{D+P_{r}}\right)
$$

Here, $f_{p}$ describes the fraction of protected HSPCs in the transplant product, $D$ the dose or total number of infused HSPCs, and $P_{r}$ the number of residual endogenous HSPCs after conditioning (variable $P$ at time of transplant, Figure $3 \mathrm{~A}$ ). $R_{T}$ is the approximate number of new infections caused by one infected cell after $T$ cell complete reconstitution post-conditioning as defined in Equation 4 (see Materials and methods) and is inversely related to the anti-SHIV immune response at the time of ATI. Post-ATI viral control depends on the fraction of protected HSPCs in the body immediately after transplant that are protected from SHIV infection, or $\left(\frac{f_{p} D}{D+P_{r}}\right)$.

To estimate the values of $f_{p}, D$, and $P_{r}$ needed for viral control, we first estimated $R_{T}$ for each animal based on individual parameter estimates pertaining to SHIV virulence and anti-SHIV immunity. We then simulated the model for each animal using varying values of $f_{p}$ from zero to one $(0-100 \%$ CCR5-edited HSPCs), values of $D$ from $10^{6}$ to $10^{9} \mathrm{HSPCs}$, and values of $P_{r}$ from zero to $10^{7} \mathrm{HSPCs}$. 
A.
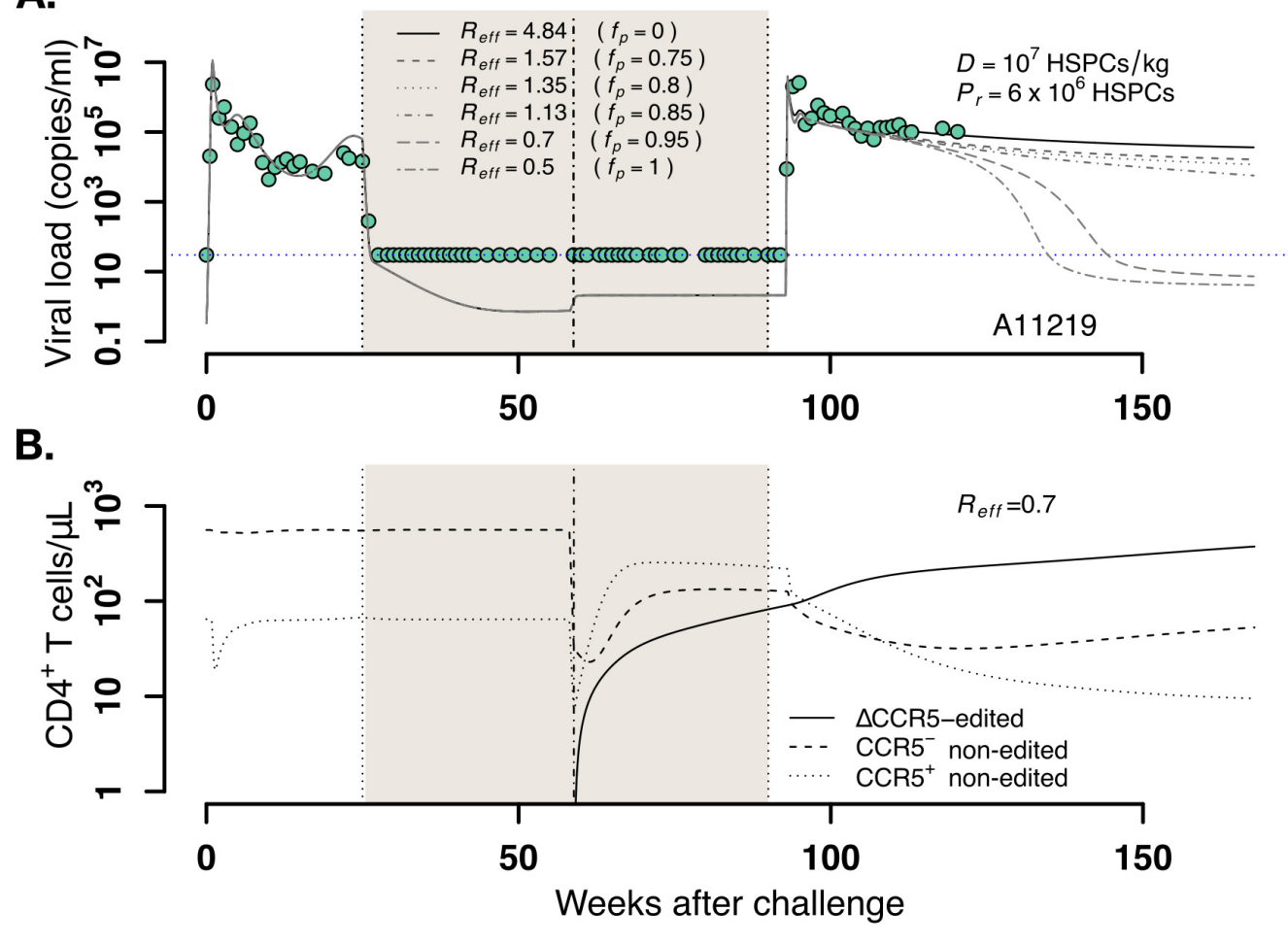

C.

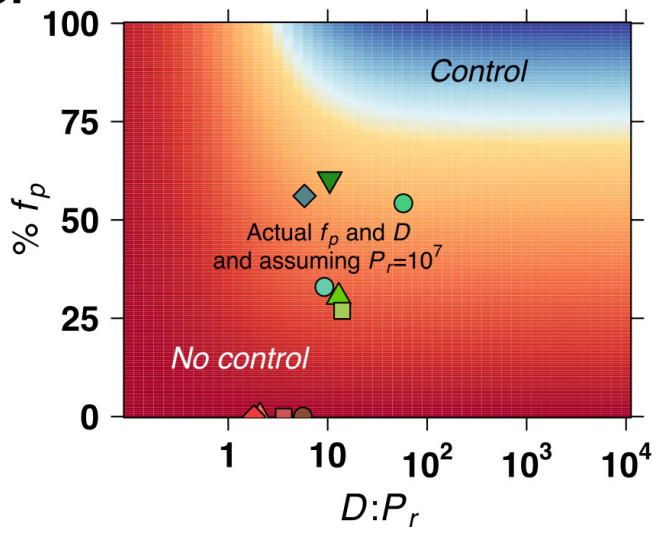

D.

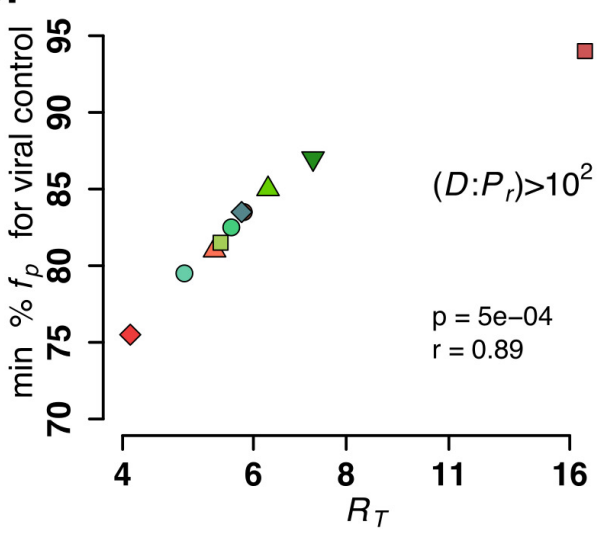

Figure 6. Model predictions of factors governing post-rebound viral control after CCR5 gene-edited hematopoietic stem and progenitor cell (HSPC) transplant. (A) Predictions for plasma viral loads post-ATI using the optimized mathematical model. Here, $R_{e f f}=R_{T}\left(1-\frac{f_{p} D}{D+P_{r}}\right)$ and is the composite determinant of viral control. Parameter estimates for animal A11219 (Figure 5-source data 3) were used to compute the effective reproductive ratio $R_{T}$. Higher values of $R_{T}$ imply poorer anti-SHIV immunity and high virulence (see Equation 4 in Materials and methods). We varied values of the fraction of HSPCs in transplant $f_{p}$, the stem cell dose $D$ as shown, and fixed the remaining number of HSPCs after TBI before transplant $P_{r}=6 \times 10^{6}$. $R_{\text {eff }}<1$ predicted spontaneous viral control 40-60 weeks after ATI. (B) A simulation with $R_{\text {eff }}=0.7$ demonstrates CCR5-edited CD4+ T cell recovery is concurrent with viral control. (C) Model predictions of the fraction of protected HSPCs in the transplant $f_{p}$ (y-axis) and the ratio of transplanted HSPCs to total infused plus remaining post-TBI HSPCs $D: P_{r}$ (x-axis) required for spontaneous viral control. The heatmap shown corresponds to animal A11200 which has $R_{T}=4$, the lowest predicted $f_{p}(76 \%)$ and $D: P_{r}(-5)$ required for post-ATI viral control (heatmaps for other animals in Figure 6-figure supplement 2). Blue shaded region represents the parameter space with post-ATI viral control or $R_{\text {eff }}<1$. Yellow-to-red region represent the parameter space with no control or $R_{e f f}>1$. Data points represent the individual values of $f_{p}$ and $D: P_{r}$ from each transplanted animal in the study. (D) Model predictions of the minimum fraction of protected HSPCs in the body $f_{p}$ for viral control (y-axis) for each animal given their calculated values for $R_{T}$ (xaxis). In all cases, the minimum $f_{p}$ corresponded to $\frac{D}{P_{r}}>100$ (Figure 6-figure supplement 2). Each color is an animal, and $\mathrm{A} 11200$ is the red diamond with the lowest value of $\min f_{p}$. p-Value calculated using Pearson's correlation test.

Figure 6 continued on next page 
Figure 6 continued

The online version of this article includes the following source data, source code and figure supplement(s) for figure 6:

Source code 1. $R$ code for plots in Figure 6A-B.

Source code 2. $R$ code for plots in Figure 6C-D.

Source data 1. Results from all simulations varying $f_{p}, D$, and $P_{r}$.

Figure supplement 1. Model predictions for post-rebound viral control after CCR5 gene-edited hematopoietic stem and progenitor cell (HSPC) transplantation based on $R_{\text {eff }}$.

Figure supplement 2. Model predictions of the fraction of protected hematopoietic stem and progenitor cell (HSPCs) in the transplant $f_{p}$ (y-axis) and the fraction of transplanted HSPCs with respect to the total infused plus remaining post-TBI HSPCs $D: P_{r}$ (x-axis) required for spontaneous viral control.

As an illustration, Figure 6A depicts projections of the model for $\triangle$ CCR5-transplanted animal A11219 for a range of values of $f_{p}$ when $D=10^{7} \mathrm{HSPCs} / \mathrm{kg}$ and $P_{r}=6 \times 10^{6} \mathrm{HSPCs}$. When $f_{p}, D$ and $P_{r}$ resulted in $R_{\text {eff }} \geq 1$, plasma virus was not controlled following viral rebound post-ATI. When $R_{\text {eff }}<$ 1, post-rebound control was observed, but only at weeks 40-60 post-ATI, following an initial decrease in viral loads beginning 30-40 weeks after ATI. In this case, post-rebound control occurred concomitantly with $\triangle$ CCR5 CD4 ${ }^{+} \mathrm{T}$ cell complete reconstitution relative to non-edited $\mathrm{CCR} 5^{+/-} \mathrm{CD}^{+}$ T cells (Figure 6B). Lower values of $R_{\text {eff }}$ resulted in earlier post-rebound control (earliest $\sim 40$ weeks).

Indeed, for all animals, post-treatment control occurred when values of $f_{p}, D$, and $P_{r}$ resulted in $R_{\text {eff }}<1$ (Figure 6-figure supplement 1). Model predictions for animal A11200 demonstrate that regardless of the fraction of protected HSPCs in the transplant $\left(f_{p}\right)$, viral control is possible only when the ratio of HSPCs in the transplant to the residual endogenous HSPCs in the body post-TBI $\left(D: P_{r}\right)$ is above 5 (Figure $6 C$ ). Moreover, if the ratio $D: P_{r}$ is greater than 5 , the minimum fraction of protected cells required is $76 \%$, and further increasing $D: P_{r}$ does not decrease $f_{p}$ significantly. From all transplanted animals we found that the minimum fraction of protected cells in the transplant $f_{p}$ varied from $76 \%$ to $94 \%$ and was positively correlated with a weaker anti-SHIV immune response of the given animal defined by $R_{T}$ (Figure 6D and Figure 6-figure supplement 2). This is consistent with Equation 1 as $R_{\text {eff }} \approx R_{T}\left(1-f_{p}\right)$ when $D \gg P_{r}$. $R_{T}$ varied from 4 to 16 across animals using individual parameter estimates in Figure 5-source data 3. The required levels for $f_{p}$ are lower in the context of more intense anti-SHIV immunologic pressure and lower viral strength. This result argues for strategies that (1) augment anti-SHIV immunity despite conditioning (lower $R_{T}$ using SHIV-specific CAR T cells, therapeutic vaccination, etc.), (2) increase the stem cell dose relative to the residual endogenous stem cells $\left(D: P_{r}\right)$ after transplant-perhaps by enhancing potency of the conditioning regimen, and (3) increase the fraction of gene-modified, SHIV-resistant cells $\left(f_{p}\right)$.

Based on the observation that viral control occurred when $C D 4^{+} \mathrm{T}$ cell subsets approached a steady state in the simulations (Figure 6A-B), we simulated the model again to determine whether viral control might occur faster if ATI was postponed at a time when more mature, protected cells have expanded. As an illustration, we simulated animal A11219 under conditions that lead to viral control: $f_{p}=0.95, D=10^{8} \mathrm{HSPCs}$ and $P_{r}=10^{7} \mathrm{HSPCs}$ with ATI occurring at 3, 14, 25, or 37 weeks after transplantation. Indeed, time to post-ATI viral control (shaded areas in Figure 7A) decreased as time to ATI was extended after transplant and as the difference between $\mathrm{CD} 4^{+} \mathrm{CCR} 5^{-}$cell density at ATI and its expected set point decreased (shaded areas in Figure 7B). In this case, $\triangle$ CCR5 CD4 ${ }^{+}$ $\mathrm{T}$ cells comprised the majority of the $\mathrm{CD} 4^{+} \mathrm{CCR} 5^{-} \mathrm{T}$ cell compartment (Figure $7 \mathrm{~B}$ ). Further, we simulated increasing times of ATI using parameter estimates for all transplanted animals but under conditions that lead to viral control $\left(f_{p}>0.95, D=10^{8} \mathrm{HSPCs}\right.$ and $\left.P_{r}=10^{7} \mathrm{HSPCs}\right)$. The model predicted the same decreasing pattern with times between transplant and ATI required to avoid viral rebound from 20 to 60 weeks (Figure 7C). This timeframe allowed all animals to achieve viral control due to $\mathrm{CD}^{+}{ }^{+} \mathrm{CCR} 5^{-}$cell densities at ATI exceeding $60-90 \%$ of the ultimate steady state value (Figure 7D). As in Figure $7 \mathrm{~B}$ for all animals $\triangle \mathrm{CCR} 5 \mathrm{CD} 4^{+} \mathrm{T}$ cells comprised the majority of the $\mathrm{CD} 4^{+} \mathrm{CCR} 5^{-} \mathrm{T}$ cell compartment.

In summary, our model predicts that post-ATI viral control during autologous HSPC transplantation is obtained when (1) the transplanted HSPC dose is significantly higher than the residual endogenous HSPCs that persist through myeloablative conditioning (in this case TBI) and (2) the fraction of protected (i.e. CCR5-edited) HSPCs in the transplant $\left(f_{p}\right)$ is sufficiently high to outcompete cells susceptible to infection and disrupt ongoing cycles of viral replication. Spontaneous post-rebound 


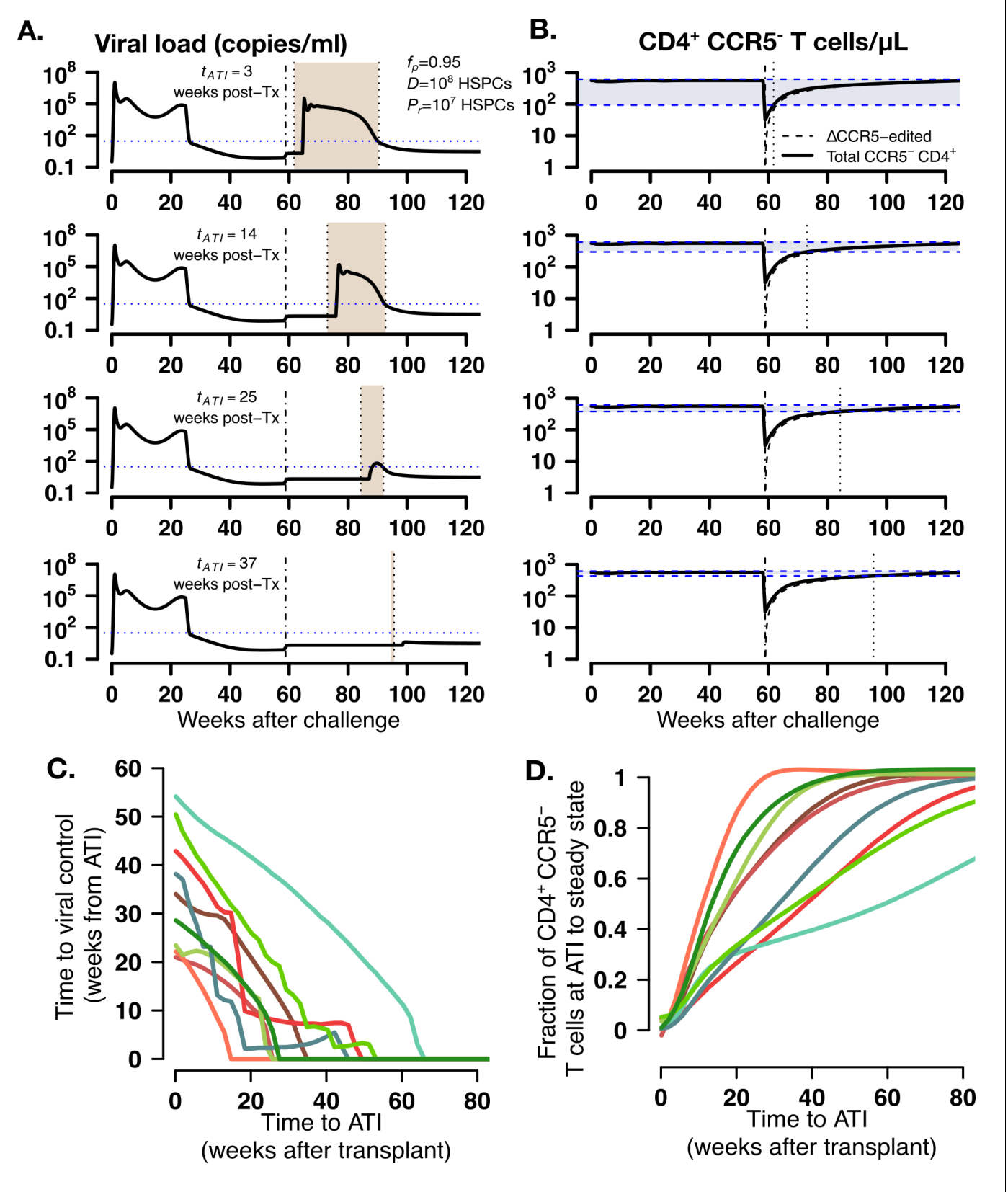

Figure 7. Model predictions of time to post-ATI viral control given varying times for the start of ATI. (A-B) Examples of projected (A) viral load and (B) total, modified and unmodified CD4 ${ }^{+} \mathrm{CCR}^{-}$(solid) and $\triangle \mathrm{CCR} 5 \mathrm{CD}^{+} \mathrm{T}$ cells (dashed) from the model for animal A11219 when $f_{p}=0.95, D=10^{8.5}$ HSPCs and $P_{r}=10^{7} \mathrm{HSPCs}$, for different times of ATI ( $t_{A T I}=3,14,25$, and 37 weeks after transplantation). Dashed-dotted vertical lines represent time of transplant. Shaded areas between the dotted lines in (A) describe the time from ATI until spontaneous viral control. Shaded areas between the blue dashed lines in (B) represent the difference between the CD4 ${ }^{+}$CCR5 ${ }^{-}$T cell concentration at ATI and the projected steady state. Dotted lines in (B) represent time of ATI. (C-D) Model predictions of the (C) time until viral control after ATI and (D) the fraction of total CD4 ${ }^{+}$CCR5 ${ }^{-}$cell concentration at ATI with respect to its steady state conditions given actual estimated parameter values for each transplanted macaque when $f_{p}=0.95, D=10^{8.5}$ HSPCs and $P_{r}=10^{7}$ HSPCs.

The online version of this article includes the following source data for figure 7:

Source data 1. Results from all simulations varying time to ATI. 
control occurs after $\mathrm{CCR} 5^{-} \mathrm{CD}^{+} \mathrm{T}$ cells achieve a steady state approximately 1 -year after transplantation. Hence, our model suggests that, under the two described conditions, prolonging time to ATI (at least 1-year post-transplantation) may increase the likelihood of rapid viral control post-ATI. Moreover, specifically tracking $\mathrm{CD}^{+} \mathrm{CCR}^{-}$(or CCR5-edited $\mathrm{CD}^{+}$) $\mathrm{T}$ cell growth and waiting for steady-state could be used as a surrogate for the decision to undergo ATI.

\section{Discussion}

Here we introduce a data-validated mathematical model that, to our knowledge, is the first to simultaneously recapitulate viral loads as well as $\mathrm{CD} 4^{+}$and $\mathrm{CD} 8^{+} \mathrm{T}$ cell subset counts in a macaque model of suppressed HIV-1 infection. In addition, our model is the first to describe dynamics of $\mathrm{CCR}^{+}$and $\mathrm{CCR}^{-} \mathrm{T}$ cells within the CD4 compartment. We performed extensive, systematic data fitting comparing 30 mechanistic models to arrive at a set of equations that most parsimoniously explains the available data. In multiple stages of modeling, we recapitulated (1) peripheral $\mathrm{CD}^{+}$and $\mathrm{CD} 8^{+} \mathrm{T}$ cell subset reconstitution dynamics following transplant and (2) T cell subset dynamics and SHIV viral rebound following ATI. Before ATI, all animals had suppressed plasma viral loads below the limit of detection, allowing analysis of $\mathrm{T}$ cell reconstitution dynamics independent of virus-mediated pressure. At each step, we applied model selection theory to select the simplest set of mechanisms capable of explaining the observed data (Burnham et al., 2002). Our model predicts that postrebound viral control might be possible during autologous gene-edited HSPC transplantation if therapy achieves (1) a sufficient fraction of gene-protected, autologous HSPCs (2) a high dose of transplant product relative to a residual endogenous population of stem cells that persists following conditioning, and (3) enhancement of SHIV-specific immune responses following transplantation. Further, our model predicts, that under these conditions, spontaneous viral control after ATI is likely if $\triangle$ CCR5 $\mathrm{T}$ cells (tracked by $\mathrm{CD} 4^{+}$CCR5 $\mathrm{T}$ cells) are allowed to reconstitute prior to ATI. These results are consistent with the cure achieved by the Berlin and London Patients who received a transplant with 100\% HIV-resistant cells after intense conditioning (Allers et alı, 2011; Hütter et alo, 2009). In the autologous setting where $100 \%$ CCR5 editing may not be feasible, adjunctive measures that augment virus-specific immunity, such as therapeutic vaccination, infusion of HIV-specific chimeric antigen receptor (CAR) T cells or use of neutralizing antibodies, may synergize with HSPC transplantation to achieve post-treatment control (Haworth et al., 2017; Zhen et al., 2017).

Although the model predicts a potential benefit for more potent conditioning that favors engraftment of SHIV-resistant cells, a more aggressive conditioning regimen may also deplete SHIV-specific immune responses and lead to less favorable toxicity profiles. On the other hand, in the absence of conditioning, the number of endogenous HSPCs will remain too high. Thus, post-rebound control following $\triangle$ CCR5 transplant requires not only highly potent myeloablative conditioning, it also requires a higher percentage of gene-edited cells to counteract the loss of SHIV-specific immunity. Furthermore, due to the high levels of endogenous HSPCs and lack of an engraftment 'niche', the long-term persistence of transplanted, CCR5-edited HSPC would be exceedingly low. Alternatively, non-genotoxic conditioning regimens that target only HSPC for transplantation may prevent the loss of SHIV-specific immune cells (Palchaudhuri et al., 2016; Czechowicz et al., 2019; Srikanthan et al., 2020).

We previously demonstrated the link between disruption of the immune response during transplant and increased magnitude of viral rebound during treatment interruption (Peterson et alo, 2017; Reeves et al., 2017). Here, we confirm that the increase of viral load median and nadir at ATI compare to the pre-ART stage is correlated with the reduction of the SHIV-specific immune response during transplant, but also predict that a reduction of viral load burden at ATI compared to pre-ART in animals receiving CCR5-edited cells in the transplant is correlated to a recovery of the SHIV-specific immunity.

Our results are somewhat limited by a small sample size of 22 animals, only 12 of which underwent $\triangle C C R 5$ transplant. For that reason, several model parameters were assumed to be the same among all animals (i.e. without random effects). However, the number of observations for each animal was large enough to discriminate among several different plausible model candidates. Due to the small sample size, we also performed projections by varying the parameters related to transplantation (i.e. dose, fraction of protected cells, and residual endogenous HSPCs) and using only the estimated individual parameters rather than sampling from estimated population distributions. 
Reassuringly, our results align with prior mechanistic studies of cellular reconstitution after stem cell transplantation (Jameson, 2002; Douek et al., 2000; Guillaume et al., 1998; Krenger et al., 2011; Roux et al., 2000). Our analysis also suggests that the majority of reconstituting $\mathrm{CD}^{+}{ }^{+} \mathrm{CCR} 5^{-} \mathrm{T}$ cells do not proliferate and have slow rates consistent with estimates of thymic export from previous studies (Douek et al., 2000; Krenger et al., 2011; Roux et alo, 2000).

Recent studies from our group and others make clear that although a preparative conditioning regimen (e.g. TBI) is essential to maximize engraftment of transplanted HSPCs, it does not clear $100 \%$ of host lymphocytes, especially those in tissues (Peterson et alı, 2017; Peterson et alo, 2018; Donahue et al., 2015; Radtke et al., 2017). The best fitting model predicts that incomplete elimination of lymphocytes by $\mathrm{TBI}$ prevents $\mathrm{CD} 4^{+} \mathrm{CCR} 5^{-}$cells from predominating post-transplant. We found that the rapid expansion of $\mathrm{CD}^{+}{ }^{+} \mathrm{CR} 5^{+}$and $\mathrm{CD} 8^{+} \mathrm{T}$ cells during the first few weeks after HSPC transplantation is most likely due to lymphopenia-induced proliferation of residual endogenous cells after TBI rather than thymic reconstitution. $\mathrm{CD}^{+}{ }^{+} \mathrm{CCR} 5^{-} \mathrm{T}$ cells arising from thymic export of both transplanted and remaining cells are overwhelmed by more rapidly populating $\mathrm{CD} 4^{+} \mathrm{CCR} 5^{+}$ $T$ cells within weeks of transplantation. Going forward, we will need to identify anatomic sites (namely viral reservoir tissues such as spleen and lymph nodes) and associated mechanisms that allow activated $\mathrm{CD} 4^{+} \mathrm{CCR} 5^{+}$to survive conditioning.

A final important observation from our model is that $\mathrm{CD} 4^{+} \mathrm{T}$ cell kinetics conducive to viral control may not be reached until 20-60 weeks after transplant. Therefore, our model suggests that ATI should be delayed until $\mathrm{CD} 4^{+} \mathrm{CCR} 5{ }^{-} \mathrm{T}$ cells reconstitute (as a proxy for $\triangle \mathrm{CCR} 5 \mathrm{CD} 4^{+} \mathrm{T}$ cell reconstitution) to their natural steady state. Furthermore, optimized timing of ATI would ideally be based on reconstitution of all $\mathrm{CD} 4^{+}$and $\mathrm{CD} 8^{+} \mathrm{T}$ cell subsets ensuring approximately steady state levels before discontinuing ART.

In conclusion, our mathematical model recapitulates, to an unprecedented degree of accuracy and detail, the complex interplay between reconstituting SHIV-susceptible CD4 ${ }^{+} \mathrm{T}$ cells, SHIV-resistant $\mathrm{CD}^{+}{ }^{+} \mathrm{T}$ cells, infected cells, virus-specific immune cells, and replicating virus following autologous, CCR5-edited HSPC transplantation. Our results illustrate the capabilities of mathematical models to glean insight from preclinical animal models and highlight that modeling will be required to optimize strategies for HIV cure.

\section{Materials and methods}

\section{Study design}

We employed a multi-stage approach using ordinary differential equation models of cellular and viral dynamics to analyze data from SHIV-infected pig-tailed macaques that underwent autologous HSPC transplantation during ART and to find conditions for post-rebound control when gene-edited cells were included in the transplant product. First, we modeled T cell dynamics and reconstitution following transplant and before ATI, assuming that low viral loads during suppressive ART do not affect cell dynamics (Figure 1B). In the second stage, we added viral load data during primary infection and after ATI and fit models to the T cell and viral dynamics simultaneously from data pre- and postATI (Figure 1C). We then used the most parsimonious model, as determined by AIC, to perform simulated experiments for different transplant conditions, focusing on variables including fraction of protected cells, dose, depletion of HSPCs after conditioning, and time of ATI after transplant to find thresholds for viral control post-ATI.

\section{Experimental data}

Twenty-two juvenile pigtail macaques were intravenously challenged with 9500 TCID50 SHIV1157ipd3N4 (SHIV-C) (Peterson et al., 2017; Peterson et al., 2018). After 6 months, the macaques received combination antiretroviral therapy (ART): tenofovir (PMPA), emtricitabine (FTC), and raltegravir (RAL). After $\sim 30$ weeks on ART, 17 animals received total body irradiation (TBI) followed by transplantation of autologous HSPCs. In 12/17 animals the transplant product included CCR5 geneedited HSPCs ( $\triangle$ CCR5 group); HSPC products in 5/17 animals were not edited (WT group). After an additional 25 weeks following transplant, when viral load was well suppressed, animals underwent ATI (Peterson et al., 2017). A control group of five animals did not receive TBI or HSPC transplantation and underwent ATI after $\sim 50$ weeks of treatment. One and six of the animals in the WT and 
$\triangle$ CCR5 groups, respectively, were necropsied before ATI. One of the animals in the control group was necropsied before ATI (Figure 1A). Plasma viral loads and absolute peripheral T-cell counts from $\mathrm{CD}^{+}{ }^{+} \mathrm{CCR} 5{ }^{-}, \mathrm{CD}^{+}{ }^{+} \mathrm{CCR}^{+}$and total $\mathrm{CD}^{+}$and subsets (naive, central memory $\left[\mathrm{T}_{\mathrm{CM}}\right.$, and effector memory $\left[\mathrm{T}_{\mathrm{EM}}\right]$ ) were measured for the control and WT group as described previously (Peterson et al., 2017). We analyzed peripheral T cell counts and plasma viral load from infection until 43 weeks post-transplant ( 25 weeks pre-ATI and $\sim 20$ weeks post-ATI).

\section{Mathematical modeling of $\mathbf{T}$ cell reconstitution dynamics}

We modeled the kinetics of $\mathrm{CD}^{+}$and $\mathrm{CD}^{+} \mathrm{T}$ cell subsets in blood including residual endogenous, transplanted cells that home to the BM, and progenitor cells in the BM/thymus both from transplant and residual endogenous. We included $\mathrm{CD} 8^{+} \mathrm{T}$ cells in the model because $\mathrm{CD} 8^{+}$and $\mathrm{CD} 4^{+} \mathrm{T}$ cells may arise from new naïve cells from the thymus and compete with each other for resources that impact clonal expansion and cell survival (Jameson, 2002; Mehr and Perelson, 1997; Margolick and Donnenberg, 1997). We assumed that expansion of CD4 ${ }^{+}$and $C D 8^{+} \mathrm{T}$ cells in the blood derives from: (1) export of naïve cells differentiated from a progenitor compartment in the BM/Thymus (Guillaume et al., 1998; Spits, 2002) ([either from transplanted (Douek et al., 2000; Douek et al., 1998)] or residual endogenous CD34 ${ }^{+}$HSPCs) and further differentiation to an activated effector state (Voehringer et al., 2008; Bender et al., 1999; Kieper and Jameson, 1999; Sallusto et al., 2004; Le Saout et al., 2008; Sprent and Surh, 2011; Buchholz et al., 2013; Farber et al., 2014; Kaech et al., 2002), or (2) lymphopenia-induced division of mature, residual endogenous cells that persist through myeloablative TBI (Jameson, 2002; Schluns et al., 2002; Schluns et al., 2000; Goldrath et al., 2004; Voehringer et al., 2008) as factors that drive T cell proliferation are more accessible (i.e. self-MHC molecules on antigen-presenting cells [Bender et al., 1999; Kieper and Jameson, 1999; Tanchot, 1997] and $\gamma$-chain cytokines such as IL-7 and IL-15 [Schluns et al., 2002; Schluns et al., 2000; Goldrath et al., 2004; Tan et al., 2001]). However, as they grow, cells compete for access to these resources, limiting clonal expansion (Jameson, 2002) such that logistic growth models are appropriate (Mehr and Perelson, 1997).

In our mathematical model, transplanted HSPCs $T$ home to the bone marrow at a rate $k_{e}$. We assumed a single-cell compartment for $T$ cell progenitors in the bone marrow (BM)/thymus represented by variable $P$. We assumed that $P$ renew logistically with maximum rate $r_{p}$, differentiate into naïve $C D 4^{+}$and $\mathrm{CD}^{+} \mathrm{T}$ cells at rates $\lambda_{f}$ and $\lambda_{e}$, respectively, or are cleared at rate $d_{p}$ (Stiehl and Marciniak-Czochra, 2011; Stiehl et al., 2014; Stiehl and Marciniak-Czochra, 2017). We assumed two $\mathrm{CD}^{+} \mathrm{T}$ cell compartments: SHIV-non-susceptible, i.e. CD4 ${ }^{+} \mathrm{T}$ cells that do not express CCR5 (CD4 ${ }^{+}$CCR5 ${ }^{-} \mathrm{T}$ cells) $\mathrm{N}$, and a SHIV-susceptible compartment, $\mathrm{S}$ (CD4 ${ }^{+} \mathrm{CCR}^{+} \mathrm{T}$ cells). Only the $\mathrm{N}$ compartment includes $\mathrm{CD}^{+}$naïve cells migrating from the thymus (Bleul et al., 1997; Zaitseva et al., 1998; Berkowitz et al., 1998) at an input rate $\lambda_{f} P$ cells per day (Douek et al., 2000; McCune, 1997). N cells grow with maximum rate $r_{n}$, upregulate CCR5 (27) at rate $\lambda_{n}$, and are cleared from the periphery at rate $d_{n}$. The $S$ compartment does not have a thymic input but can grow with maximum division rate $r_{s}$, downregulate CCR5 (27) at a rate $\lambda_{s}$, and are cleared at rate $d_{s}$. We model $\mathrm{CD}^{+} \mathrm{T}$ cell reconstitution assuming a compartment for naïve and central memory cells, $M$, and a compartment for the effector memory subset, $E$. We assumed that $M$ cells have thymic input of $\lambda_{e} P$ cells per day, grow logistically with maximum division rate $r_{m}$ differentiate to effector memory at rate $\lambda_{m}$, and are cleared at rate $d_{m}$. The $E$ compartment grows with maximum division rate $r_{e}$ and is cleared at rate $d_{e}$. We added variables $T_{p}, P_{p}, N_{p 1}$ and $N_{p 2}$, representing CCR5 genemodified- transplanted HSPCs, T cell progenitor cells in BM/thymus, and blood $\mathrm{CD}^{+} \mathrm{CCR}^{-} \mathrm{T}$ cells with $\mathrm{CD}^{+}{ }^{+} \mathrm{CCR} 5^{-}$and $\mathrm{CD}^{+} \mathrm{CCR} 5^{+}$kinetics, respectively. These compartments have the same structure as $T, P, N$ and $S$, but with two differences. First, the value of $T_{p}$ at transplantation is a fraction $f_{p}$ of the total number of infused cells. Second, the $N_{p 1}$ cell compartment do not upregulate CCR5 when transitioning to $N_{p 2}$. We model the competition of $\mathrm{CD}^{+}$and $\mathrm{CD} 8^{+} \mathrm{T}$ cells for resources that allow cell division using a logistic equation that depends on the difference between the total number of competing cells, i.e. $A=N_{p 1}+N_{p 2}+N+S+M+E$, and a carrying capacity $K$ (Jameson, 2002). Under these assumptions we constructed the following model form: 


$$
\begin{gathered}
\frac{d T_{p}}{d t}=-k_{e} T_{p} \\
\frac{d P_{p}}{d t}=k_{e} T_{p}+\hat{r}_{P}\left(1-\frac{A}{K_{p}}\right) P_{p} \\
\frac{d N_{p 1}}{d t}=\lambda_{f} P_{p}+\hat{r}_{n}\left(1-\frac{A}{K_{n}}\right) N_{p 1}+\lambda_{s} N_{p 2} \\
\frac{d N_{p 2}}{d t}=\hat{r}_{s}\left(1-\frac{A}{K_{s}}\right) N_{p 2}+\lambda_{n} N_{p 1} \\
\frac{d T}{d t}=-k_{e} T \\
\frac{d P}{d t}=k_{e} T+\hat{r}_{p}\left(1-\frac{A}{K_{p}}\right) P \\
\frac{d N}{d t}=\lambda_{f} P+\hat{r}_{n}\left(1-\frac{A}{K_{n}}\right) N+\lambda_{s} S \\
\frac{d S}{d t}=\hat{r}_{s}\left(1-\frac{A}{K_{s}}\right) S+\lambda_{n} N \\
\frac{d M}{d t}=\lambda_{e}\left(P+P_{p}\right)+\hat{r}_{m}\left(1-\frac{A}{K_{m}}\right) M \\
\frac{d E}{d t}=\lambda_{m} M+\hat{r}_{e}\left(1-\frac{A}{k_{e}}\right) E
\end{gathered}
$$

where $\hat{r}_{p}=r_{p}-\left(\lambda_{f}+\lambda_{e}+d_{p}\right), \hat{r}_{n}=r_{n}-\left(\lambda_{n}+d_{n}\right), \hat{r}_{s}=r_{s}-\left(\lambda_{s}+d_{s}\right), \hat{r}_{m}=r_{m}-\left(\lambda_{m}+d_{m}\right), \hat{r}_{e}=r_{e}-d_{e}$, as well as $K_{w}=K \frac{\hat{r}_{w}}{r_{w}}$ for each model variable $w \in\{p, n, s, m, e\}$. We did this re-parameterization to have compound parameters that were identifiable.

When simulating the model, we assumed $t_{0}$ as the time of transplantation. For the transplant groups the system is in a transient stage due to conditioning (TBI) at $t_{0}$, therefore initial values cannot be obtained from steady state equations. Transplantation is modeled as $T\left(t_{0}\right)=\left(1-f_{p}\right) D$ and $T_{p}\left(t_{0}\right)=f_{p} D$. For the control group we used $t_{0}$ at a similar time relative to the transplant groups. Since the control group did not have any transplantation or TBI, we assumed $T\left(t_{0}\right)=T_{p}\left(t_{0}\right)=P_{p}\left(t_{0}\right)=N_{p}\left(t_{0}\right)=0$. Other initial values were calculated assuming steady state: $P\left(t_{0}\right)=\frac{q_{2} q_{3} q_{4} K_{p}}{\left(q_{1}+1\right) q_{3} q_{4}+q_{2}\left(q_{4}+1\right)}, N\left(t_{0}\right)=\frac{q_{1} q_{3} q_{4} K_{p}}{\left(q_{1}+1\right) q_{3} q_{4}+q_{2}\left(q_{4}+1\right)}, S\left(t_{0}\right)=\frac{q_{3} q_{4} K_{p}}{\left(q_{1}+1\right) q_{3} q_{4}+q_{2}\left(q_{4}+1\right)}, M\left(t_{0}\right)=\frac{q_{2} q_{4} K_{p}}{\left(q_{1}+1\right) q_{3} q_{4}+q 2\left(q_{4}+1\right)}$ and $E\left(t_{0}\right)=\frac{q_{2} K_{p}}{\left(q_{1}+1\right) q_{3} q_{4}+q 2\left(q_{4}+1\right)}$. Here $q_{1}=\frac{\hat{r}_{s}}{\lambda_{n}}\left(\frac{K_{p}}{K_{s}}-1\right), \quad q_{2}=\frac{\hat{r}_{n}}{\lambda_{f}}\left(q_{1}\left(\frac{K_{p}}{K_{n}}-1\right)-\lambda_{s}\right), \quad q_{3}=\frac{\hat{r}_{m}}{\lambda_{e}}\left(\frac{K_{p}}{K_{m}}-1\right) \quad$ and $q_{4}=\frac{\hat{r}_{e}}{\lambda_{m}}\left(\frac{K_{p}}{K_{e}}-1\right)$. A parsimonious, curated version of this model was selected from a series of models with varying mechanistic and statistical complexity (Figure 3-source data 2).

\section{Mathematical modeling of SHIV infection and T cell response dynamics}

We next adapted the curated $T$ cell reconstitution model by combining several adaptations of the canonical model of viral dynamics (Reeves et al., 2017; Perelson, 2002; Perelson et al., 1997; Hill et al., 2018; Borducchi et al., 2016; De Boer, 2007; Wodarz and Nowak, 1999; Pandit and de Boer, 2016). Here, virus $V$ infects only $C D 4^{+} C C R 5^{+}$T cells (Ho et al., 2009) $S$ at rate $\beta$. We modeled ART by reducing the infection rate to zero. A fraction $\tau$ of the infected cells produce virus, $I_{p}$, and the other fraction become unproductively infected, $I_{u}$ (Reeves et al., 2017; Doitsh et al., 2010; Matrajt et al., 2014). $I_{P}$ cells arise only from activation of a persistent set of latently infected cells at rate $\xi \bar{L}$. We modeled ATI by assuming infection $\beta$ is greater than zero after some delay following ATI. We approximate this delay as the sum of the time of ART to washout ( 3 days) and the time of successful activation $\left(t_{s a}\right)$ of a steady set of latently infected cells. For simplicity, we assumed that $\xi \bar{L}=\frac{1}{t_{s a}}$ and assumed that $t_{s a}$ has lognormal distribution among the animal population with high variance (Conway et al., 2019; Hill et al., 2014; Prague et al., 2019). All infected cells die at rate $\delta_{l}$ (Reeves et al., 2017). I cells produce virus at a rate $\pi$ per cell, that is cleared at rate $\gamma \cdot \mathrm{CD}^{+} M$ cells proliferate in the presence of infection with maximum rate $\omega_{8}$. A fraction $f$ of these cells become SHIV-specific CD8 ${ }^{+}$effector T cells, $E_{h}$, that are removed at a rate $d_{h}$ (De Boer, 2007; Wodarz and Nowak, 1999; Wodarz et al., 2000). These effector cells may reduce virus production $(\pi)$ or increase infected cell clearance $\left(\delta_{l}\right)$ by $1 /\left(1+\theta E_{h}\right)$ or by $\left(1+\kappa E_{h}\right)$, respectively (Elemans et al., 2011; Klatt et al., 2010; Wong et al., 2010; Borducchi et al., 2016; Cardozo et al., 2018). We assumed that non-susceptible CD4 ${ }^{+} \mathrm{T}$ cells may upregulate CCR5 and replenish the susceptible pool during infection (Okoye et al., 2007; Okoye et al., 2012; Okoye and Picker, 2013) with rate $\omega_{4}$. For cell 
growth the total number of competing cells is given by $A=N_{p 1}+N_{p 2}+N+S+I_{p}+I_{u}+M+E+E_{h}$. The model in Equation 2 is modified to include:

$$
\begin{aligned}
& \frac{d N}{d t}=\lambda_{f} P+\hat{r}_{n}\left(1-\frac{A}{K_{n}}\right) N+\lambda_{s} S-\omega_{4} \frac{I_{p}+I_{u}}{1+\frac{I_{1}+H_{u}}{I_{50}}} N \\
& \frac{d S}{d t}=\hat{r}_{s}\left(1-\frac{A}{K_{s}}\right) S+\lambda_{n} N-\beta V S+\omega_{4} \frac{I_{p}+I_{u}}{1+\frac{I_{p} u_{u}}{I_{50}}} N \\
& \frac{d I_{p}}{d t}=\tau \beta V S-\delta_{I}\left(1+\kappa E_{h}\right) I_{p}+\xi \bar{L} \\
& \frac{d I_{u}}{d t}=(1-\tau) \beta V S-\delta_{I}\left(1+\kappa E_{h}\right) I_{u} \\
& \frac{d V}{d t}=\frac{1}{1+\theta E_{h}} \pi I_{p}-\gamma V \\
& \frac{d M}{d t}=\lambda_{e}\left(P+P_{p}\right)+\hat{r}_{m}\left(1-\frac{A}{K_{m}}\right) M+\omega_{8}(1-2 f) \frac{I_{p}+I_{u}}{1+\frac{p_{1}+H_{L}}{I_{50}}} M \\
& \frac{d E_{h}}{d t}=\omega_{8} f \frac{I_{p}+I_{u}}{1+\frac{I_{p}+I_{u}}{I_{50}}} M-d_{h} E_{h} .
\end{aligned}
$$

When simulating this model, we assume $t_{0}=0$ as the moment of SHIV challenge, and $t_{x}$ as the moment of transplantation after challenge. We modeled conditioning by: (1) adding a term $-k_{T} C$ in all blood cell compartments $C \in\left\{N, S, I_{p}, I_{u}, M, E, E_{h}\right\}$ and (2) the term $-k_{H} P$ for the HSPC compartment $P . k_{T}$ and $k_{H}$ are different than zero only during the 2 days before transplant $\left(t_{x}-2 \leq t<t_{x}\right)$. Transplantation is modeled as an input only when $t=t_{x}$ to cell compartments $T$ and $T_{p}$ with amounts $\left(1-f_{p}\right) D$ and $f_{p} D$, respectively. A parsimonious version of this model was selected from a series of models with varying mechanistic and statistical complexity (Figure 3-source data 2).

\section{Nonlinear mixed-effects modeling}

To fit our models (Equations 2,3) to the transplant data, we used a nonlinear mixed-effects modeling approach (Lavielle, 2014). Within this approach, we modeled a state variable vector $v$ with observations at time $i$ for each animal $j$ as $\log _{10} v_{i j}=f_{v}\left(t_{i j}, \Psi_{j}\right)+\epsilon_{v}$. Here, $f_{v}$ describes the solution of the nonlinear models in Equations 2 or 3 for the state variable vector $v$ at observation time $t_{i j}$ with animal-specific parameter set $\Psi_{j}$. The distribution of measurement noise is assumed as $\epsilon_{v} \sim \mathcal{N}\left(0, \sigma_{v}^{2}\right)$.

In the mixed-effects model, it is assumed that for an animal $j$ each single parameter $\psi_{j} \in \Psi_{j}$ is drawn from a probability distribution across the population. This distribution includes the fixed effects $\bar{\psi}$ representing the median value over the population, and the random effects $\eta_{j}$ representing its variability in the population, assumed to be normally distributed with standard deviation $\sigma_{\psi}$, that is $\eta_{j} \sim \mathcal{N}\left(0, \sigma_{\psi}^{2}\right)$. We assumed that the random effects of the parameters $\eta_{j}$ might not be independent. In that case, the vector of random effects $\eta_{j}$ follows a multinormal distribution: $\eta \sim \mathcal{N}(0, \Omega)$, being $\Omega$ the variance-covariance matrix based on the values $\sigma_{\psi}$ and correlations between the individual parameters in $\eta$.

We fit each model to all data points from all animals simultaneously using a maximum likelihood approach. We assumed that individual observations of each state variable $v_{i j}$ for each animal $j$ at each time point $t_{i j}$ are independent. For each model, we obtained the Maximum Likelihood Estimation (MLE) of the standard deviation of the measurement error for the observations $\sigma_{v}$, and each parameter fixed effects $\bar{\psi}$ and standard deviation of the random effects $\sigma_{\psi}$ (or elements in matrix $\Omega$ when applicable) using the Stochastic Approximation of the Expectation Maximization (SAEM) algorithm embedded in the Monolix software (http://www.lixoft.eu).

\section{Fitting T cell reconstitution before ATI}

We first fit the observed blood T cell kinetics after HSPC transplantation and before analytical treatment interruption (ATI) using the model in Equation 2. During this procedure, we defined the vector $v^{(1)}$ to model the $\log _{10}$ of the observed blood $\mathrm{CD}^{+} \mathrm{CCR} 5, \mathrm{CD}^{+}{ }^{+} \mathrm{CCR} 5^{+}$, total $\mathrm{CD} 8^{+}, \mathrm{CD}^{+} \mathrm{T}_{\mathrm{N}}+$ $\mathrm{T}_{\mathrm{CM}}$, and $\mathrm{CD}^{+} \mathrm{T}_{\mathrm{EM}}$ cell counts which are represented in Equation 2 by the variables $\left\{N+N_{p 1}+N_{p 2}, S, C, M, E\right\}$, respectively with $C=M+E$ and solution $f^{(1)}$.

We defined the statistical form of each parameter in $\Psi^{(1)}$ in the following form: parameters $r_{p}^{j}, r_{m}^{j}, r_{e}^{j}, \lambda_{f}^{j}, \lambda_{e}^{j}, \lambda_{n}^{j}, \lambda_{s}^{j}, \lambda_{m}^{j}$ were modeled as $\psi_{j}=\bar{\psi} e^{n_{j}}$; parameter $K_{p}^{j}$ was modeled as $\psi_{j}=10^{\bar{\psi}+n_{j}}$; $K_{n}^{j}, K_{s}^{j}, K_{m}^{j}, K_{e}^{j}$ were modeled as $\psi_{j}=10^{K_{p}^{j}-\bar{\psi}_{e^{n_{j}}}}$; and initial values in the transplant group: 
$N^{j}\left(t_{0}\right), S^{j}\left(t_{0}\right), M^{j}\left(t_{0}\right)$ and $E^{j}\left(t_{0}\right)$ had the model $\psi_{j}=10^{\bar{\psi}+n_{j}}$. We explored the possibility that $r_{n}=0$, in that case we assumed $\hat{d}_{n}^{j}=\lambda_{n}^{j}\left(1+\bar{\psi} e^{n_{j}}\right)$. We fixed the HSPC homing rate $k_{e}=1 /$ day (Lapidot et alı, 2005; Chute, 2006), and $f_{p}$ and $D$ as described in Figure 3-source data 1. Since at $t_{0}$ the system is in a transient stage due to conditioning (TBI), we estimated blood cell concentrations at $t_{0}$, but fixed the number of HSPCs that remained in the BM/thymus $P\left(t_{0}\right)$ to $6 \times 10^{6}$ based on the estimated minimum number of infused HSPCs needed for engraftment in the same animal model (Radtke et al., 2017).

We fit instances of models with varying statistical and mechanistic complexity in Equation 2 to blood T cell counts during transplant and before ATI (Figure 1B) assuming that one or multiple mechanisms are absent, or that certain mechanisms have equal kinetics (Figure 3-source data 2 includes all 24 competing models with the different statistical assumptions).

\section{Fitting $T$ cell and viral load dynamics before and after ATI}

Next, we fit the model in Equations 2-3 to the pre- and post-ATI blood T cell counts and plasma viral loads (Figure 1B). Here, we defined $v^{(2)}$ for variables $\left\{N+N_{p 1}+N_{p 2}, R, C_{4}, C_{8}, M, E, V\right\}$ with $V$ indicating the observed plasma viral load, $N+N_{p 1}+N_{p 2}$ indicating the observed blood CD4 ${ }^{+}$CCR5 T cell concentration, $R=S+I_{p}+I_{u}$ the observed blood $\mathrm{CD}^{+}{ }^{+} \mathrm{CCR}^{+} \mathrm{T}$ cell concentration, $C_{8}$ the total $\mathrm{CD}^{+} \mathrm{T}$ cell concentration, $C_{4}=R+N+N_{p 1}+N_{p 2}$ the total $\mathrm{CD}^{+} \mathrm{T}$ cell concentration and the others state-variables as specified for $v^{(1)}$. We included $C_{4}$ because we had total CD4 ${ }^{+} \mathrm{T}$ cell counts, but $\mathrm{CD}^{+}{ }^{+}$subset counts during the primary infection stage were not available in many of the animals. For this model, we defined the parameter set $\Psi^{(2)}$ by adding to the parameters in the previous section the parameters relative to virus dynamics (i.e. $\Psi^{(2)}=\left\{\Psi^{(1)}, \kappa^{j}, \theta^{j}, \beta^{j}, \pi^{j}, \omega_{4}^{j}, \omega_{8}^{j}, I_{50}^{j}, d_{h}^{j}, t_{s a}^{j}\right\}$ but fixing the values in $\Psi^{(1)}$ to the MLE values using Figure 3-source data 3). For parameters $\kappa^{j}, \theta^{j}, \beta^{j}, \pi^{j}, \omega_{4}^{j}, \omega_{8}^{j}, I_{50}^{j}$, we used a model with form $\psi_{j}=10^{\bar{\psi}+n_{j}}$, and for $d_{h}^{j}$ and $t_{s a}^{j}$ we used $\psi_{j}=\bar{\psi} e^{n_{j}}$. We included the possibility that immunity might be different at ATI compared to pre-ART by assuming the forms $\psi^{j, A T I}=10^{\bar{\psi}+n_{j}+\varsigma_{\psi, A T I}}$ for $\omega_{8}^{j}$ and $I_{50}^{j}$, and $\psi^{j, A T I}=\bar{\psi} e^{n_{j}+\varsigma_{\psi, A T I}}$ for $d_{h}^{j}$ during ATI. We evaluated single or combination of mechanistic hypotheses along with different statistical assumptions as listed in Figure 5-source data 1 using AIC. $V(0)$ was fixed to a small value below the limit of detection, and $I_{p}(0)$ and $I_{u}(0)$ were calculated as $\tau c V(0) / \pi$ and $(1-\tau) c V(0) / \pi$, respectively. We fixed the following parameters: $\gamma=23 /$ day (Ramratnam et al., 1999), $\delta_{I}=1 /$ day (Markowitz et al., 2003; Cardozo et al., 2017), $\tau=0.05$ (Doitsh et alo, 2010), and $f=0.9$ (Borducchi et alo, 2016). The value of $k_{h}$ was constrained to obtain a value of the HSPCs after conditioning $P\left(t_{x}\right)=P_{r}=6 \times 10^{6}$ (Radtke et al., 2017). We fixed values of $t_{x}, f_{p}$ and $D$ as described in Figure 3source data 1.

We fit several instances of the model in Equation 3 to pre- and post-ATI blood T cell counts and plasma viral loads (Figure 1B) using the best model obtained for Equation 2 (Figure 5-source data 1 includes all four competing models and respective statistical assumptions). At the time of SHIV infection, values for the cell compartments were calculated from steady state equations with the same form as for the group without transplantation ('control') in the previous section.

\section{Model selection}

To determine the best and most parsimonious model among the instances, we computed the loglikelihood $(\log L$ ) and the Akaike Information Criteria (AIC=-2log $L+2 m$, where $m$ is the number of parameters estimated) (Burnham et al., 2002). We assumed a model has similar support from the data if the difference between its AIC and the best model (lowest) AIC is less than two (Burnham et al., 2002).

\section{Effective reproductive ratio when $r_{n}=0$ and $\kappa=0$}

We calculated an approximate effective reproductive ratio $R_{\text {eff }}$ for our model (Equations 2,3) by computing the average number of offspring produced by one productively infected cell $I_{p}$ at ATI assuming all cell compartments have reached steady state after transplantation during ART. This number is the product of the average lifespan of one $I_{p}$, the virus production rate by this latently infected cell, the lifespan of produced virions from this cell, the rate at which each virion infects the 
pool of susceptible cells at steady state, the fraction of these infections that become productive and the reduction of virus production, cell infection, and cell death by SHIV-specific immune cells at ATI. Using this approach, we obtain that $R_{e f f}=\frac{\tau \beta \bar{S} \pi}{\gamma \delta_{I}\left(1+\theta \bar{E}_{h}\right)}$, with $\bar{S} \approx \frac{\lambda_{f} \bar{P}}{\frac{\lambda_{n} \hat{S}_{s}}{\lambda_{n}}\left(\frac{K_{p}}{K_{s}}-1\right)-\lambda_{s}}$ and $\bar{E}_{h} \approx \frac{f \omega_{8} \lambda_{e} K_{p}}{a d_{h} \delta_{I} t_{s a} \hat{r}_{m}\left(\frac{K_{p}}{K_{m}}-1\right)}$ the steady state values of variables $S$ (SHIV-susceptible cells) and $E_{h}$ (SHIV-specific effector cells) during ART, with $a=\frac{\lambda_{e}}{\hat{r}_{m}\left(\frac{K_{p}}{K_{m}}-1\right)}+\frac{\lambda_{f} \lambda_{n}}{\hat{d}_{n} \hat{r}_{s}\left(\frac{K_{p}}{K_{s}}-1\right)-\lambda_{s} \lambda_{n}}+\frac{\lambda_{f} \hat{r}_{s}\left(\frac{K_{p}}{K_{s}}-1\right)}{\hat{d}_{n} \hat{r}_{s}\left(\frac{K_{p}}{K_{s}}-1\right)-\lambda_{s} \lambda_{n}}+\frac{\lambda_{e} \lambda_{m}}{\hat{r}_{m}\left(\frac{K_{p}}{K_{m}}-1\right) \hat{r}_{e}\left(\frac{K_{p}}{K_{e}}-1\right)}+\frac{f \omega_{s} \lambda_{e}}{d_{h} \delta_{I} t_{s a} \hat{r}_{m}\left(\frac{K_{p}}{K_{m}}-1\right)}$. By assuming that the total amount of infused cells (dose $D$ and fraction of CCR5-editing $f_{p}$ ) home to the BM/Thymus rapidly, and that the amount of remaining HSPCs after TBI and immediately before transplant is $P\left(t_{x}\right)=P_{r}$, the approximate steady state for $P$ is $\bar{P} \approx \frac{K_{p}}{a} \cdot \frac{\left(1-f_{p}\right) D+P_{r}}{D+P_{r}}=\frac{K_{p}}{a}\left(1-\frac{f_{p} D}{D+P_{r}}\right)$. Together this gives the following expression for the effective reproductive ratio:

$$
R_{e f f}=R_{T}\left(1-\frac{f_{p} D}{D+P_{r}}\right), \text { with } R_{T}=\frac{\tau \beta \pi \lambda_{e} K_{p}}{a \gamma \delta_{I}\left[\frac{\hat{d}_{n} \hat{r}_{s}}{\lambda_{n}}\left(\frac{K_{p}}{K_{s}}-1\right)-\lambda_{s}\right]\left(1+\theta \bar{E}_{h}\right)}
$$

Here, $R_{T}$ then represents the effective reproductive ratio during transplant in the absence of gene-editing when cells have reached steady state.

\section{Acknowledgements}

This study was supported by grants from the National Institutes of Health, National Institute of Allergy and Infectious Diseases (UM1 Al126623, R01 Al150500). ERD is supported by the National Center for Advancing Translational Sciences of the National Institutes of Health under Award Number KL2 TR002317. DBR is supported by a Washington Research Foundation postdoctoral fellowship, and a CFAR NIA P30 AI027757. NHP studies were supported by NIH P51 OD010425. The funders had no role in study design, data collection and analysis, decision to publish, or preparation of the manuscript. The content is solely the responsibility of the authors and does not necessarily represent the official views of the National Institutes of Health or the Washington Research Foundation.

\section{Additional information}

Competing interests

Hans-Peter Kiem: H.-P.K has served on advisory boards for Rocket Pharmaceuticals, Homology medicines and CSL for research unrelated to this manuscript. The other authors declare that no competing interests exist.

Funding

\begin{tabular}{|c|c|c|}
\hline Funder & Grant reference number & Author \\
\hline $\begin{array}{l}\text { National Institute of Allergy } \\
\text { and Infectious Diseases }\end{array}$ & UM1 Al126623 & $\begin{array}{l}\text { E Fabian Cardozo-Ojeda } \\
\text { Christopher W Peterson } \\
\text { Hans-Peter Kiem } \\
\text { Joshua T Schiffer }\end{array}$ \\
\hline $\begin{array}{l}\text { National Institute of Allergy } \\
\text { and Infectious Diseases }\end{array}$ & R01 Al150500 & $\begin{array}{l}\text { E Fabian Cardozo-Ojeda } \\
\text { Joshua T Schiffer }\end{array}$ \\
\hline $\begin{array}{l}\text { National Center for Advancing } \\
\text { Translational Sciences }\end{array}$ & KL2 TR002317 & Elizabeth R Duke \\
\hline Center for AIDS Research & $\begin{array}{l}\text { New Investigator Award P30 } \\
\text { Al027757 }\end{array}$ & Daniel B Reeves \\
\hline $\begin{array}{l}\text { Washington Research Founda- } \\
\text { tion }\end{array}$ & Postdoctoral Fellowship & Daniel B Reeves \\
\hline National Institutes of Health & P51 OD010425 & Hans-Peter Kiem \\
\hline
\end{tabular}


The funders had no role in study design, data collection and interpretation, or the decision to submit the work for publication.

Author contributions

E Fabian Cardozo-Ojeda, Software, Formal analysis, Funding acquisition, Validation, Investigation, Visualization, Methodology, Writing - original draft, Writing - review and editing, Developed the mathematical models, wrote all code, performed all calculations and derivations, ran the models in Monolix and analyzed output data; Elizabeth R Duke, Visualization, Methodology, Writing - review and editing, Development of mechanistic mathematical models; Christopher W Peterson, Data curation, Writing - review and editing; Daniel B Reeves, Methodology, Writing - review and editing, Development of mechanistic mathematical models; Bryan T Mayer, Methodology, Writing - review and editing, Contributed ideas and support for statistical models and analyses; Hans-Peter Kiem, Data curation, Funding acquisition, Writing - review and editing; Joshua T Schiffer, Conceptualization, Supervision, Funding acquisition, Methodology, Writing - original draft, Writing - review and editing

Author ORCIDs

E Fabian Cardozo-Ojeda (iD https://orcid.org/0000-0001-8690-9896

Daniel B Reeves (iD) http://orcid.org/0000-0001-5684-9538

Joshua T Schiffer (iD https://orcid.org/0000-0002-2598-1621

Ethics

Animal experimentation: The data used in this work were collected in strict accordance with the recommendations in the Guide for the Care and Use of Laboratory Animals of the National Institutes of Health. The study protocol was approved by the Institutional Animal Care and Use Committees (IACUC) protocols (\#3235-03) of the Fred Hutchinson Cancer Research Center and the University of Washington.

Decision letter and Author response

Decision letter https://doi.org/10.7554/eLife.57646.sa1

Author response https://doi.org/10.7554/eLife.57646.sa2

\section{Additional files}

Supplementary files

- Transparent reporting form

Data availability

All data generated or analysed during this study are included in the manuscript and supporting files. Source data files have been provided for Figures 2 to 7. Details of the source data for each figure are in the Transparent Reporting form.

\section{References}

Allers K, Hütter G, Hofmann J, Loddenkemper C, Rieger K, Thiel E, Schneider T. 2011. Evidence for the cure of HIV infection by CCR5 $\Delta 32 / \Delta 32$ stem cell transplantation. Blood 117:2791-2799. DOI: https://doi.org/10.1182/ blood-2010-09-309591, PMID: 21148083

Bender J, Mitchell T, Kappler J, Marrack P. 1999. Cd4+ T cell division in irradiated mice requires peptides distinct from those responsible for thymic selection. Journal of Experimental Medicine 190:367-374.

DOI: https://doi.org/10.1084/jem.190.3.367

Berkowitz RD, Beckerman KP, Schall TJ, McCune JM. 1998. CXCR4 and CCR5 expression delineates targets for HIV-1 disruption of T cell differentiation. Journal of Immunology 161:3702-3710.

Blazek D, Teque F, Mackewicz C, Peterlin M, Levy JA. 2016. The CD8+ cell non-cytotoxic antiviral response affects RNA polymerase II-mediated human immunodeficiency virus transcription in infected CD4+ cells. Journal of General Virology 97:220-224. DOI: https://doi.org/10.1099/jgv.0.000326 
Bleul CC, Wu L, Hoxie JA, Springer TA, Mackay CR. 1997. The HIV coreceptors CXCR4 and CCR5 are differentially expressed and regulated on human T lymphocytes. PNAS 94:1925-1930. DOI: https://doi.org/10. 1073/pnas.94.5.1925, PMID: 9050881

Borducchi EN, Cabral C, Stephenson KE, Liu J, Abbink P, Ng'ang'a D, Nkolola JP, Brinkman AL, Peter L, Lee BC, Jimenez J, Jetton D, Mondesir J, Mojta S, Chandrashekar A, Molloy K, Alter G, Gerold JM, Hill AL, Lewis MG, et al. 2016. Ad26/MVA therapeutic vaccination with TLR7 stimulation in SIV-infected rhesus monkeys. Nature 540:284-287. DOl: https://doi.org/10.1038/nature20583, PMID: 27841870

Buchholz VR, Flossdorf M, Hensel I, Kretschmer L, Weissbrich B, Gräf P, Verschoor A, Schiemann M, Höfer T, Busch DH. 2013. Disparate individual fates compose robust CD8+ T cell immunity. Science 340:630-635. DOI: https://doi.org/10.1126/science.1235454, PMID: 23493420

Burnham KP, Anderson DR, Selection M. 2002. Model Selection and Multimodel Inference: . New York: Springer-Verlag. DOI: https://doi.org/10.1016/j.ecolmodel.2003.11.004

Cardozo EF, Andrade A, Mellors JW, Kuritzkes DR, Perelson AS, Ribeiro RM. 2017. Treatment with integrase inhibitor suggests a new interpretation of HIV RNA decay curves that reveals a subset of cells with slow integration. PLOS Pathogens 13:e1006478. DOI: https://doi.org/10.1371/journal.ppat.1006478, PMID: 2867887 9

Cardozo EF, Apetrei C, Pandrea I, Ribeiro RM. 2018. The dynamics of simian immunodeficiency virus after depletion of CD8+ cells. Immunological Reviews 285:26-37. DOI: https://doi.org/10.1111/imr.12691, PMID: 30129200

Chun TW, Finzi D, Margolick J, Chadwick K, Schwartz D, Siliciano RF. 1995. In vivo fate of HIV-1-infected T cells: quantitative analysis of the transition to stable latency. Nature Medicine 1:1284-1290. DOI: https://doi.org/10. 1038/nm1295-1284, PMID: 7489410

Chun TW, Carruth L, Finzi D, Shen X, DiGiuseppe JA, Taylor H, Hermankova M, Chadwick K, Margolick J, Quinn TC, Kuo YH, Brookmeyer R, Zeiger MA, Barditch-Crovo P, Siliciano RF. 1997. Quantification of latent tissue reservoirs and total body viral load in HIV-1 infection. Nature 387:183-188. DOI: https://doi.org/10.1038/ 387183a0, PMID: 9144289

Chute JP. 2006. Stem cell homing. Current Opinion in Hematology 13:399-406. DOI: https://doi.org/10.1097/01. moh.0000245698.62511.3d, PMID: 17053451

Conway JM, Perelson AS, Li JZ. 2019. Predictions of time to HIV viral rebound following ART suspension that incorporate personal biomarkers. PLOS Computational Biology 15:e1007229. DOI: https://doi.org/10.1371/ journal.pcbi.1007229, PMID: 31339888

Czechowicz A, Palchaudhuri R, Scheck A, Hu Y, Hoggatt J, Saez B, Pang WW, Mansour MK, Tate TA, Chan YY, Walck E, Wernig G, Shizuru JA, Winau F, Scadden DT, Rossi DJ. 2019. Selective hematopoietic stem cell ablation using CD117-antibody-drug-conjugates enables safe and effective transplantation with immunity preservation. Nature Communications 10:617. DOI: https://doi.org/10.1038/s41467-018-08201-x, PMID: 3072 8354

De Boer RJ. 2007. Understanding the failure of CD8+ T-cell vaccination against simian/human immunodeficiency virus. Journal of Virology 81:2838-2848. DOI: https://doi.org/10.1128/JVI.01914-06, PMID: 17202215

Doitsh G, Cavrois M, Lassen KG, Zepeda O, Yang Z, Santiago ML, Hebbeler AM, Greene WC. 2010. Abortive HIV infection mediates CD4 T cell depletion and inflammation in human lymphoid tissue. Cell 143:789-801. DOI: https://doi.org/10.1016/j.cell.2010.11.001, PMID: 21111238

Donahue RE, Srinivasula S, Uchida N, Kim I, St. Claire A, Duralde G, DeGrange P, St. Claire M, Reba RC, Bonifacino AC, Krouse AE, Metzger ME, Paik CH, Lane HC, Tisdale JF, Di Mascio M. 2015. Discordance in lymphoid tissue recovery following stem cell transplantation in rhesus macaques: an in vivo imaging study. Blood 126:2632-2641. DOI: https://doi.org/10.1182/blood-2015-07-657346

Douek DC, McFarland RD, Keiser PH, Gage EA, Massey JM, Haynes BF, Polis MA, Haase AT, Feinberg MB, Sullivan JL, Jamieson BD, Zack JA, Picker LJ, Koup RA. 1998. Changes in thymic function with age and during the treatment of HIV infection. Nature 396:690-695. DOI: https://doi.org/10.1038/25374, PMID: 9872319

Douek DC, Vescio RA, Betts MR, Brenchley JM, Hill BJ, Zhang L, Berenson JR, Collins RH, Koup RA. 2000. Assessment of thymic output in adults after haematopoietic stemcell transplantation and prediction of T-cell reconstitution. The Lancet 355:1875-1881. DOI: https://doi.org/10.1016/S0140-6736(00)02293-5

Douek DC, Picker LJ, Koup RA. 2003. T cell dynamics in HIV-1 infection. Annual Review of Immunology 21:265304. DOI: https://doi.org/10.1146/annurev.immunol.21.120601.141053, PMID: 12524385

Elemans M, Seich Al Basatena NK, Klatt NR, Gkekas C, Silvestri G, Asquith B. 2011. Why don't CD8+ T cells reduce the lifespan of SIV-infected cells in vivo? PLOS Computational Biology 7:e1002200. DOI: https://doi. org/10.1371/journal.pcbi.1002200, PMID: 21990968

Farber DL, Yudanin NA, Restifo NP. 2014. Human memory T cells: generation, compartmentalization and homeostasis. Nature Reviews Immunology 14:24-35. DOI: https://doi.org/10.1038/nri3567, PMID: 24336101

Finzi D, Hermankova M, Pierson T, Carruth LM, Buck C, Chaisson RE, Quinn TC, Chadwick K, Margolick J, Brookmeyer R, Gallant J, Markowitz M, Ho DD, Richman DD, Siliciano RF. 1997. Identification of a reservoir for HIV-1 in patients on highly active antiretroviral therapy. Science 278:1295-1300. DOI: https://doi.org/10.1126/ science.278.5341.1295, PMID: 9360927

Goldrath AW, Luckey CJ, Park R, Benoist C, Mathis D. 2004. The molecular program induced in T cells undergoing homeostatic proliferation. PNAS 101:16885-16890. DOI: https://doi.org/10.1073/pnas. 0407417101

Guillaume T, Rubinstein DB, Symann M. 1998. Immune reconstitution and immunotherapy after autologous hematopoietic stem cell transplantation. Blood 92:1471-1490. DOl: https://doi.org/10.1182/blood.V92.5.1471 
Gupta RK, Abdul-Jawad S, McCoy LE, Mok HP, Peppa D, Salgado M, Martinez-Picado J, Nijhuis M, Wensing AMJ, Lee H, Grant P, Nastouli E, Lambert J, Pace M, Salasc F, Monit C, Innes AJ, Muir L, Waters L, Frater J, et al. 2019. HIV-1 remission following CCR5 $\Delta 32 / \Delta 32$ haematopoietic stem-cell transplantation. Nature 568: 244-248. DOI: https://doi.org/10.1038/s41586-019-1027-4, PMID: 30836379

Gupta RK, Peppa D, Hill AL, Gálvez C, Salgado M, Pace M, McCoy LE, Griffith SA, Thornhill J, Alrubayyi A Huyveneers LEP, Nastouli E, Grant P, Edwards SG, Innes AJ, Frater J, Nijhuis M, Wensing AMJ, MartinezPicado J, Olavarria E. 2020. Evidence for HIV-1 cure after CCR5 $\Delta 2 / \Delta 32$ allogeneic haemopoietic stem-cell transplantation 30 months post analytical treatment interruption: a case report. The Lancet HIV 7:e340-e347. DOI: https://doi.org/10.1016/S2352-3018(20)30069-2, PMID: 32169158

Haworth KG, Peterson CW, Kiem HP. 2017. CCR5-edited gene therapies for HIV cure: closing the door to viral entry. Cytotherapy 19:1325-1338. DOI: https://doi.org/10.1016/j.jcyt.2017.05.013, PMID: 28751153

Henrich TJ, Hu Z, Li JZ, Sciaranghella G, Busch MP, Keating SM, Gallien S, Lin NH, Giguel FF, Lavoie L, Ho VT, Armand P, Soiffer RJ, Sagar M, Lacasce AS, Kuritzkes DR. 2013. Long-term reduction in peripheral blood HIV type 1 reservoirs following reduced-intensity conditioning allogeneic stem cell transplantation. Journal of Infectious Diseases 207:1694-1702. DOI: https://doi.org/10.1093/infdis/jit086, PMID: 23460751

Henrich TJ, Hanhauser E, Marty FM, Sirignano MN, Keating S, Lee TH, Robles YP, Davis BT, Li JZ, Heisey A, Hill AL, Busch MP, Armand P, Soiffer RJ, Altfeld M, Kuritzkes DR. 2014. Antiretroviral-free HIV-1 remission and viral rebound after allogeneic stem cell transplantation: report of 2 cases. Annals of Internal Medicine 161:319. DOI: https://doi.org/10.7326/M14-1027, PMID: 25047577

Henrich TJ, Hanhauser E, Harrison LJ, Palmer CD, Romero-Tejeda M, Jost S, Bosch RJ, Kuritzkes DR. 2016. CCR5- $\Delta 32$ heterozygosity, HIV-1 reservoir size, and lymphocyte activation in individuals receiving Long-term suppressive antiretroviral therapy. Journal of Infectious Diseases 213:766-770. DOl: https://doi.org/10.1093/ infdis/jiv504, PMID: 26512140

Hill AL, Rosenbloom DI, Fu F, Nowak MA, Siliciano RF. 2014. Predicting the outcomes of treatment to eradicate the latent reservoir for HIV-1. PNAS 111:13475-13480. DOI: https://doi.org/10.1073/pnas.1406663111، PMID: 25097264

Hill AL, Rosenbloom DIS, Nowak MA, Siliciano RF. 2018. Insight into treatment of HIV infection from viral dynamics models. Immunological Reviews 285:9-25. DOI: https://doi.org/10.1111/imr.12698, PMID: 30129208

Ho O, Larsen K, Polacino P, Li Y, Anderson D, Song R, Ruprecht RM, Hu SL. 2009. Pathogenic infection of Macaca nemestrina with a CCR5-tropic subtype-C simian-human immunodeficiency virus. Retrovirology 6:65. DOI: https://doi.org/10.1186/1742-4690-6-65, PMID: 19602283

Hütter G, Nowak D, Mossner M, Ganepola S, Müssig A, Allers K, Schneider T, Hofmann J, Kücherer C, Blau O, Blau IW, Hofmann WK, Thiel E. 2009. Long-Term control of HIV by CCR5 Delta32/Delta32 Stem-Cell transplantation. New England Journal of Medicine 360:692-698. DOI: https://doi.org/10.1056/ NEJMoa0802905

Jameson SC. 2002. Maintaining the norm: t-cell homeostasis. Nature Reviews Immunology 2:547-556. DOI: https://doi.org/10.1038/nri853, PMID: 12154374

Kaech SM, Wherry EJ, Ahmed R. 2002. Effector and memory T-cell differentiation: implications for vaccine development. Nature Reviews Immunology 2:251-262. DOI: https://doi.org/10.1038/nri778, PMID: 12001996

Kieper WC, Jameson SC. 1999. Homeostatic expansion and phenotypic conversion of naïve T cells in response to self peptide/MHC ligands. PNAS 96:13306-13311. DOI: https://doi.org/10.1073/pnas.96.23.13306, PMID: 10557316

Klatt NR, Shudo E, Ortiz AM, Engram JC, Paiardini M, Lawson B, Miller MD, Else J, Pandrea I, Estes JD, Apetrei C, Schmitz JE, Ribeiro RM, Perelson AS, Silvestri G. 2010. CD8+ lymphocytes control viral replication in SIVmac239-infected rhesus macaques without decreasing the lifespan of productively infected cells. PLOS Pathogens 6:e1000747. DOI: https://doi.org/10.1371/journal.ppat.1000747, PMID: 20126441

Krenger W, Blazar BR, Holländer GA. 2011. Thymic T-cell development in Allogeneic stem cell transplantation. Blood 117:6768-6776. DOI: https://doi.org/10.1182/blood-2011-02-334623, PMID: 21427289

Lapidot T, Dar A, Kollet O. 2005. How do stem cells find their way home? Blood 106:1901-1910. DOI: https:// doi.org/10.1182/blood-2005-04-1417, PMID: 15890683

Lavielle M. 2014. Mixed Effects Models for the Population Approach: Models, Tasks, Methods and Tools. Boca Raton: Chapman and Hall/CRC.

Le Saout C, Mennechet S, Taylor N, Hernandez J. 2008. Memory-like CD8+ and CD4+ T cells cooperate to break peripheral tolerance under lymphopenic conditions. PNAS 105:19414-19419. DOI: https://doi.org/10.1073/ pnas.0807743105, PMID: 19033460

Margolick JB, Donnenberg AD. 1997. T-cell homeostasis in HIV-1 infection. Seminars in Immunology 9:381-388. DOI: https://doi.org/10.1006/smim.1997.0096, PMID: 9405267

Markowitz M, Louie M, Hurley A, Sun E, Di Mascio M, Perelson AS, Ho DD. 2003. A novel antiviral intervention results in more accurate assessment of human immunodeficiency virus type 1 replication dynamics and T-cell decay in vivo. Journal of Virology 77:5037-5038. DOI: https://doi.org/10.1128/JVI.77.8.5037-5038.2003, PMID: 12663814

Matrajt L, Younan PM, Kiem HP, Schiffer JT. 2014. The majority of CD4+ T-cell depletion during acute simianhuman immunodeficiency virus SHIV89.6P infection occurs in uninfected cells. Journal of Virology 88:32023212. DOI: https://doi.org/10.1128/JVI.03428-13, PMID: 24390339

McCune JM. 1997. Thymic function in HIV-1 disease. Seminars in Immunology 9:397-404. DOI: https://doi.org/ 10.1006/smim.1997.0098, PMID: 9405269 
Mehr R, Perelson AS. 1997. Blind T-cell homeostasis and the CD4/CD8 ratio in the Thymus and peripheral blood. Journal of Acquired Immune Deficiency Syndromes and Human Retrovirology 14:387-398. DOI: https://doi. org/10.1097/00042560-199704150-00001, PMID: 9170412

Okoye A, Meier-Schellersheim M, Brenchley JM, Hagen SI, Walker JM, Rohankhedkar M, Lum R, Edgar JB, Planer SL, Legasse A, Sylwester AW, Piatak M, Lifson JD, Maino VC, Sodora DL, Douek DC, Axthelm MK, Grossman Z, Picker LJ. 2007. Progressive CD4+ central-memory T cell decline results in CD4+ effectormemory insufficiency and overt disease in chronic SIV infection. Journal of Experimental Medicine 204:21712185. DOI: https://doi.org/10.1084/jem.20070567

Okoye AA, Rohankhedkar M, Abana C, Pattenn A, Reyes M, Pexton C, Lum R, Sylwester A, Planer SL, Legasse A, Park BS, Piatak M, Lifson JD, Axthelm MK, Picker LJ. 2012. Naive T cells are dispensable for memory CD4+ T cell homeostasis in progressive simian immunodeficiency virus infection. Journal of Experimental Medicine 209: 641-651. DOI: https://doi.org/10.1084/jem.20112071

Okoye AA, Picker LJ. 2013. P. L. J., CD4+ t-cell depletion in HIV infection: mechanisms of immunological failure. Immunological Reviews 254:54-64. DOI: https://doi.org/10.1111/imr.12066, PMID: 23772614

Palchaudhuri R, Saez B, Hoggatt J, Schajnovitz A, Sykes DB, Tate TA, Czechowicz A, Kfoury Y, Ruchika F, Rossi DJ, Verdine GL, Mansour MK, Scadden DT. 2016. Non-genotoxic conditioning for hematopoietic stem cell transplantation using a hematopoietic-cell-specific internalizing immunotoxin. Nature Biotechnology 34:738745. DOI: https://doi.org/10.1038/nbt.3584, PMID: 27272386

Pandit A, de Boer RJ. 2016. HIV-1 CCR5 gene therapy will fail unless it is combined with a suicide gene. Scientific Reports 5:srep18088. DOI: https://doi.org/10.1038/srep18088

Perelson AS, Essunger P, Cao Y, Vesanen M, Hurley A, Saksela K, Markowitz M, Ho DD. 1997. Decay characteristics of HIV-1-infected compartments during combination therapy. Nature 387:188-191. DOI: https:// doi.org/10.1038/387188a0, PMID: 9144290

Perelson AS. 2002. Modelling viral and immune system dynamics. Nature Reviews Immunology 2:28-36. DOI: https://doi.org/10.1038/nri700, PMID: 11905835

Peterson CW, Wang J, Norman KK, Norgaard ZK, Humbert O, Tse CK, Yan JJ, Trimble RG, Shivak DA, Rebar EJ, Gregory PD, Holmes MC, Kiem HP. 2016. Long-term multilineage engraftment of autologous genome-edited hematopoietic stem cells in nonhuman primates. Blood 127:2416-2426. DOI: https://doi.org/10.1182/blood2015-09-672337, PMID: 26980728

Peterson CW, Benne C, Polacino P, Kaur J, McAllister CE, Filali-Mouhim A, Obenza W, Pecor TA, Huang ML, Baldessari A, Murnane RD, Woolfrey AE, Jerome KR, Hu SL, Klatt NR, DeRosa S, Sékaly RP, Kiem HP. 2017. Loss of immune homeostasis dictates SHIV rebound after stem-cell transplantation. JCI Insight 2:e91230. DOI: https://doi.org/10.1172/jci.insight.91230, PMID: 28239658

Peterson CW, Wang J, Deleage C, Reddy S, Kaur J, Polacino P, Reik A, Huang ML, Jerome KR, Hu SL, Holmes MC, Estes JD, Kiem HP. 2018. Differential impact of transplantation on peripheral and tissue-associated viral reservoirs: implications for HIV gene therapy. PLOS Pathogens 14:e1006956. DOI: https://doi.org/10.1371/ journal.ppat.1006956, PMID: 29672640

Peterson CW, Kiem HP. 2019. Lessons from London and Berlin: designing A scalable gene therapy approach for HIV cure. Cell Stem Cell 24:685-687. DOI: https://doi.org/10.1016/j.stem.2019.04.010, PMID: 31051132

Prague M, Gerold JM, Balelli I, Pasin C, Li JZ, Barouch DH, Whitney JB, Hill AL. 2019. Viral rebound kinetics following single and combination immunotherapy for HIV/SIV. bioRxiv. 700401. DOI: https://doi.org/10.1101/ 700401

Radtke S, Adair JE, Giese MA, Chan YY, Norgaard ZK, Enstrom M, Haworth KG, Schefter LE, Kiem HP. 2017. A distinct hematopoietic stem cell population for rapid multilineage engraftment in nonhuman primates. Science Translational Medicine 9:eaan1145. DOI: https://doi.org/10.1126/scitranslmed.aan1145, PMID: 29093179

Ramratnam B, Bonhoeffer S, Binley J, Hurley A, Zhang L, Mittler JE, Markowitz M, Moore JP, Perelson AS, Ho DD. 1999. Rapid production and clearance of HIV-1 and hepatitis $C$ virus assessed by large volume plasma apheresis. The Lancet 354:1782-1785. DOI: https://doi.org/10.1016/S0140-6736(99)02035-8

Reeves DB, Peterson CW, Kiem H-P, Schiffer JT. 2017. Autologous stem cell transplantation disrupts adaptive immune responses during rebound simian/Human immunodeficiency virus viremia. Journal of Virology $\mathbf{9 1 :}$ e00095-00017. DOI: https://doi.org/10.1128/JVI.00095-17

Roux E, Dumont-Girard F, Starobinski M, Siegrist CA, Helg C, Chapuis B, Roosnek E. 2000. Recovery of immune reactivity after T-cell-depleted bone marrow transplantation depends on thymic activity. Blood 96:2299-2303. DOI: https://doi.org/10.1182/blood.V96.6.2299, PMID: 10979980

Salgado M, Kwon M, Gálvez C, Badiola J, Nijhuis M, Bandera A, Balsalobre P, Miralles P, Buño I, MartinezLaperche C, Vilaplana C, Jurado M, Clotet B, Wensing A, Martinez-Picado J, Diez-Martin JL, IciStem Consortium. 2018. Mechanisms that contribute to a profound reduction of the HIV-1 reservoir after allogeneic stem cell transplant. Annals of Internal Medicine 169:674-683. DOI: https://doi.org/10.7326/M18-0759, PMID: 30326031

Sallusto F, Geginat J, Lanzavecchia A. 2004. Central memory and effector memory T cell subsets: function, generation, and maintenance. Annual Review of Immunology 22:745-763. DOI: https://doi.org/10.1146/ annurev.immunol.22.012703.104702, PMID: 15032595

Schluns KS, Kieper WC, Jameson SC, Lefrançois L. 2000. Interleukin-7 mediates the homeostasis of naïve and memory CD8 T cells in vivo. Nature Immunology 1:426-432. DOI: https://doi.org/10.1038/80868, PMID: 11062503 
Schluns KS, Williams K, Ma A, Zheng XX, Lefrançois L. 2002. Cutting edge: requirement for IL-15 in the generation of primary and memory antigen-specific CD8 T cells. The Journal of Immunology 168:4827-4831. DOI: https://doi.org/10.4049/jimmunol.168.10.4827, PMID: 11994430

Shridhar V, Chen Y, Gupta P. 2014. The CD8 antiviral factor (CAF) can suppress HIV-1 transcription from the long terminal repeat (LTR) promoter in the absence of elements upstream of the CATATAA box. Virology Journal 11:130. DOI: https://doi.org/10.1186/1743-422X-11-130, PMID: 25048949

Spits H. 2002. Development of alphabeta T cells in the human Thymus. Nature Reviews Immunology 2:760-772. DOI: https://doi.org/10.1038/nri913, PMID: 12360214

Sprent J, Surh CD. 2011. Normal T cell homeostasis: the conversion of naive cells into memory-phenotype cells. Nature Immunology 12:478-484. DOI: https://doi.org/10.1038/ni.2018, PMID: 21739670

Srikanthan MA, Humbert O, Haworth KG, Ironside C, Rajawat YS, Blazar BR, Palchaudhuri R, Boitano AE, Cooke MP, Scadden DT, Kiem HP. 2020. Effective Multi-lineage engraftment in a mouse model of fanconi Anemia using Non-genotoxic Antibody-Based conditioning. Molecular Therapy - Methods \& Clinical Development 17: 455-464. DOI: https://doi.org/10.1016/j.omtm.2020.02.001, PMID: 32226796

Stiehl T, Baran N, Ho AD, Marciniak-Czochra A. 2014. Clonal selection and therapy resistance in acute leukaemias: mathematical modelling explains different proliferation patterns at diagnosis and relapse. Journal of the Royal Society Interface 11:20140079. DOl: https://doi.org/10.1098/rsif.2014.0079

Stiehl T, Marciniak-Czochra A. 2011. Characterization of stem cells using mathematical models of multistage cell lineages. Mathematical and Computer Modelling 53:1505-1517. DOl: https://doi.org/10.1016/j.mcm.2010.03. 057

Stiehl T, Marciniak-Czochra A. 2017. Stem cell self-renewal in regeneration and Cancer: insights from mathematical modeling. Current Opinion in Systems Biology 5:112-120. DOI: https://doi.org/10.1016/j.coisb. 2017.09.006

Tan JT, Dudl E, LeRoy E, Murray R, Sprent J, Weinberg KI, Surh CD. 2001. IL-7 is critical for homeostatic proliferation and survival of naive T cells. PNAS 98:8732-8737. DOI: https://doi.org/10.1073/pnas.161126098, PMID: 11447288

Tanchot C. 1997. Differential requirements for survival and proliferation of CD8 na\&iuml; ve or memory T cells. Science 276:2057-2062. DOI: https://doi.org/10.1126/science.276.5321.2057

Tebas P. 2014. Gene editing of CCR5 in autologous CD4 T cells of persons infected with HIV. New England Journal of Medicine 370:901-910. DOI: https://doi.org/10.1056/NEJMoa1300662

Voehringer D, Liang HE, Locksley RM. 2008. Homeostasis and effector function of lymphopenia-induced "memory-like" T cells in constitutively T cell-depleted mice. The Journal of Immunology 180:4742-4753. DOI: https://doi.org/10.4049/jimmunol.180.7.4742, PMID: 18354198

Wodarz D, Page KM, Arnaout RA, Thomsen AR, Lifson JD, Nowak MA. 2000. A new theory of cytotoxic Tlymphocyte memory: implications for HIV treatment. Philosophical Transactions of the Royal Society of London. Series B: Biological Sciences 355:329-343. DOI: https://doi.org/10.1098/rstb.2000.0570

Wodarz D, Nowak MA. 1999. Specific therapy regimes could lead to long-term immunological control of HIV. PNAS 96:14464-14469. DOI: https://doi.org/10.1073/pnas.96.25.14464, PMID: 10588728

Wong JK, Strain MC, Porrata R, Reay E, Sankaran-Walters S, Ignacio CC, Russell T, Pillai SK, Looney DJ, Dandekar S. 2010. In vivo CD8+ T-cell suppression of siv viremia is not mediated by CTL clearance of productively infected cells. PLOS Pathogens 6:e1000748. DOI: https://doi.org/10.1371/journal.ppat.1000748, PMID: 20126442

Zaitseva MB, Lee S, Rabin RL, Tiffany HL, Farber JM, Peden KW, Murphy PM, Golding H. 1998. CXCR4 and CCR5 on human thymocytes: biological function and role in HIV-1 infection. Journal of Immunology 161:31033113. PMID: 9743377

Zhang L, Yu W, He T, Yu J, Caffrey RE, Dalmasso EA, Fu S, Pham T, Mei J, Ho JJ, Zhang W, Lopez P, Ho DD. 2002. Contribution of human alpha-defensin 1, 2, and 3 to the anti-HIV-1 activity of CD8 antiviral factor. Science 298:995-1000. DOI: https://doi.org/10.1126/science.1076185, PMID: 12351674

Zhen A, Peterson CW, Carrillo MA, Reddy SS, Youn CS, Lam BB, Chang NY, Martin HA, Rick JW, Kim J, Neel NC, Rezek VK, Kamata M, Chen ISY, Zack JA, Kiem HP, Kitchen SG. 2017. Long-term persistence and function of hematopoietic stem cell-derived chimeric antigen receptor T cells in a nonhuman primate model of HIV/ AIDS. PLOS Pathogens 13:e1006753. DOI: https://doi.org/10.1371/journal.ppat.1006753, PMID: 29284044 